\title{
ARENIZAÇÃO: TRANSFIGURAÇÃO DA PAISAGEM ATRAVÉS DE IMAGENS
}

\author{
SANDY PATCH: LANDSCAPE TRANSFIGURATION THROUGH \\ IMAGES
}

ARENIZACIÓN: TRANSFIGURACIÓN DEL PAISAJE A TRAVÉS DE IMÁGENES

Dirce Maria Antunes Suertegaray

POSGEA - UFRGS

dircesuerte@gmail.com

\begin{abstract}
Resumo: Neste artigo, trata-se do processo de arenização no sudoeste do Rio Grande do Sul (RS), construído como uma narrativa, a partir da utilização de fotografias. O objetivo é resgatar processos observados durante os trabalhos de campo e ampliar as informações, neste caso, de forma qualitativa. Resgata questóes e hipóteses construídas a partir dos estudos referentes aos areais entre os anos de 1983 e 1987 e das pesquisas posteriores, que permitiram a decifração desse processo há mais de 30 anos. O registro e as descrições sobre esse processo são baseados na fotografia. Constitui um texto de primeira aproximação ao tema, destinada a professores e a estudantes.
\end{abstract}

Palavras-chave: Arenização. Areais. Sudoeste do RS.

Abstract: This article deals with the sandy patch process in the southwest of Rio Grande do Sul state as a narrative, from the use of photographs. The objective is to rescue processes observed during the fieldwork and to expand the information, in this case, in a qualitative way. It rescues questions and hypotheses built from the studies referring to the sand sheets between 1983 and 1987 and its subsequent researches, which allowed the interpreting of this process since 30 years ago. The record and descriptions about this process have photography as its basis. It is a text of first approximation to the theme, intended for teachers and students.

Keywords: Sandization. Sand spots. Southwestern RS state.

Resumen: En este artículo se trata del proceso de arenización en el suroeste de Rio Grande do Sul (RS), construido como una narrativa, a partir de la utilización de fotografías. El objetivo es rescatar procesos observados durante los trabajos de campo y ampliar las informaciones, en este caso, de forma cualitativa. Resuelve cuestiones e hipótesis construidas a partir de los estudios referentes a los arenales entre los ańos 1983 y 1987 y en investigaciones 
posteriores, que permitieron la comprensión de ese proceso desde hace más de 30 años. El registro y las descripciones sobre este proceso se basan en la fotografía. Constituye un texto de primera aproximación al tema, destinado a profesores y a estudiantes.

Palabras clave: Arenización. Arenal. Suroeste de RS.

\section{INTRODUÇẤO}

Este artigo resgata um tema abordado na tese de Suertegaray (1987), que diz respeito aos processos de expansão dos areais no Sudoeste do Rio Grande do Sul. No presente texto, o objetivo é resgatar processos observados à época e ampliar as informaçóes, neste caso, de forma qualitativa. Trata-se do resgate de uma afirmação construída a partir dos estudos referentes aos areais entre os anos 1983 e 1987 e das pesquisas posteriores, que permitiram a decifração desse processo há mais de 30 anos. Neste tempo, acompanhou-se, através da observação em campo, a evolução dessas áreas, em diferentes locais no sudoeste do RS.

Aqui, o registro e as descrições sobre esse processo são baseados na fotografia. Ela permitiu o registro temporal da evolução e, em certa medida, esta análise sugere novos caminhos de investigação.

\section{O PERCURSO CONSTRUTIVO}

Os procedimentos operacionais com os quais foi feito este relato, estão embasados em formas de construção geográfica consideradas clássicas, ou seja, o trabalho de campo, acompanhado de imagem. Neste processo, o que mudou foi, em parte, a substituição do desenho, do croqui, pela imagem, pela fotografia.

A fotografia foi considerada, por muito tempo, a expressão mais fiel do que era visto; é dito dela que "vale mais do que 1000 palavras". No entanto, embora neste texto ela seja utilizada como objeto central na explicitação do tema, é necessário fazer algumas considerações sobre captação de imagens.

Para ser claro, as fotografias não dizem nada já que não recorrem nem à palavra nem à escrita. Nós as vemos, olhamos para elas, mas não as ouvimos, da mesma maneira que não podemos lê-las. Permanecem mudas. E até deveríamos encontrar um qualificativo melhor, pois este faz por demais referência à privação da palavra: ser mudo significa que não pode falar. Mas será que as fotografias quereriam falar sem poder fazê-lo? Nada é menos certo. Qualificá-las de "silenciosas" seria talvez mais apropriado na medida em que esse epíteto designa um estado (o silêncio) mais do que uma ausência.

No entanto, essa característica das fotografias de propor uma visão em silêncio sofre constantemente a investida daqueles muito numerosos, que querem lhes fazer dizer algo. De modo corriqueiro, cada clichê fica acompanhado de uma "1egenda" que nos indica o que, nela, devemos •ler" (em latim, legenda significa "o que deve ser lido"). Correntemente também lemos a legenda antes de olhar a foto e, assim, temos tendência de re-conhecer" nela (sem por vezes nos darmos 
conta disso) o que esse texto liminar nos incita a ver. Manuais, programas escolares ambicionam nos ensinar a "ler as imagens" como se o visual somente pudesse ser entendido reduzindo se ao textual. (MARESCA, 2012, p. 37).

Entretanto, considero, em relação às imagens, que:

A pergunta recorrente, sobre se irão substituir as palavras, ainda não teve uma resposta definitiva. Se no passado os desenhos complementavam as observaçóes em campo, hoje é a fotografia que exerce essa tarefa. A exemplo do texto e da escrita, a apreensão da intencionalidade de quem fez a fotografia tanto nos pode tornar seu cúmplice quanto pode despertar sentimentos contrários o que não invalida pensarmos que a fotografia envolveu o mundo e que o mundo foi envolvido pela fotografia e pela imagem. (SUERTEGARAY, 2017, p. 27).

Este é o caminho metodológico deste artigo: tenta-se, seguindo a tradição, elaborar alguma legenda para as imagens, de forma sintética. A justificativa e a inspiração, nesta construção, vêm da leitura do artigo $O$ silêncio das imagens. Desse mesmo texto, o parágrafo abaixo expressa o caminho metodológico: "caminante no hay camino el camino se hace al andar".

Usar o tempo para fotografar significa se dar o tempo de ter uma primeira visão das coisas, sem procurar ir mais longe, mas sem querer também não perder nada. Ver, olhar, descrever o que se oferece a nós, no instante presente, sem se deixar logo levar por associaçóes de ideias, reminiscências, hipóteses que nos afastam da realidade. Sem logo procurar entender. Permanecer mais perto do real, em especial quando nos surpreende, quando ele não expressa docilmente o que estamos prontos para pensar. Aceitar. (MARESCA, 2012, p. 37).

No entanto, embora concorde com as ideias da autora, neste caso o caminho rompe com a ideia de registrar o instante pelo instante, pois ocorrem no processo de escrita associaçóes de ideias, reminiscências, hipóteses..., que nos permitem pensar; processos não visíveis.

No meu entendimento, "compreender a imagem exige conhecer o projeto de quem fotografa, suas intençôes, desejos e forma de estar no mundo. Embora vulgarizado contemporaneamente, fotografar pressupóe um projeto, uma intencionalidade, um querer produzir uma imagem a partir de um ângulo de visada, mas, também, fornece um ponto de vista, nem sempre revelado na foto, mas que se pode decifrar quando compreendemos o projeto. Embora fiquemos muitas vezes absortos nas formas e cores reveladas, as imagens permitem-nos ir mais além, instigando-nos a conhecer os projetos e a tentar perceber o sentido atribuído à natureza ou dado às vidas humanas através do olhar do fotógrafo. (SUERTEGARAY, 2017, p. 27).

Para além do projeto de elaboração deste texto, constitui esta proposta a exposição de forma didática de um conhecimento que se constrói há mais de 30 anos. Nesse sentido, o objetivo não é divulgar novos dados, mas trazer uma construção textual que prioriza a imagem, na relação com a escrita. Constitui um texto de primeira aproximaçáo ao tema, destinada a professores e a estudantes. O professor, se cabe uma sugestáo, poderá utilizá-lo 
para desencadear os estudos sobre o tema. O aluno poderá, ao analisar o texto, compreender o processo de pesquisa, que, dito de outra forma, trata-se de perguntar e de responder, desde as perguntas mais simples às mais complexas.

Para tratar desse tema, tomam-se como referência imagens para resgatar a compreensão, já construída, sobre a gênese dos areais e sobre o processo de arenização. $\mathrm{O}$ roteiro desta exposição se faz através de perguntas; estas nortearam a investigaçáo, ao longo do tempo de pesquisa, e, para a elaboração deste texto, foi feita a seleção e a descrição de imagens. As questóes são: Onde se localizam os areais?; Qual a sua distribuição?; O que são areais?; Porque ocorrem em alguns lugares e, não, em outros?; Qual é a origem dessas formas, natural ou antropogênica?; Que processos lhes deram origem?; Existe vida nos areais?; O que se observa em relação à morfodinâmica atual dos areais e na transfiguração da paisagem local?

\section{O QUE SÃO OS AREAIS? SUA LOCALIZAÇÃO E GÊNESE}

A figura 1 indica a região de ocorrência desses areais no Rio Grande do Sul. Essa região compreende o Sudoeste do Estado; mais precisamente, entre as latitudes 29o 00' S e 310 $00^{\prime} \mathrm{S}$ e as longitudes 540 30' W e 58 45' W. A área é limitada ao Norte pelo rio Ibicuí; ao Sul pelo rio Quaraí; à leste, pelo meridiano 540 30' W; e à oeste pela calha do rio Uruguai, na fronteira com a Argentina. Atinge, mais especificamente, os municípios de Alegrete, Cacequi, Itaquí, Maçambará, Manuel Viana, Quaraí, Rosário do Sul, São Borja, São Francisco de Assis e Unistalda. 
Figura 1 - Localização e distribuição dos areais na fronteira sudoeste do Rio Grande do Sul.

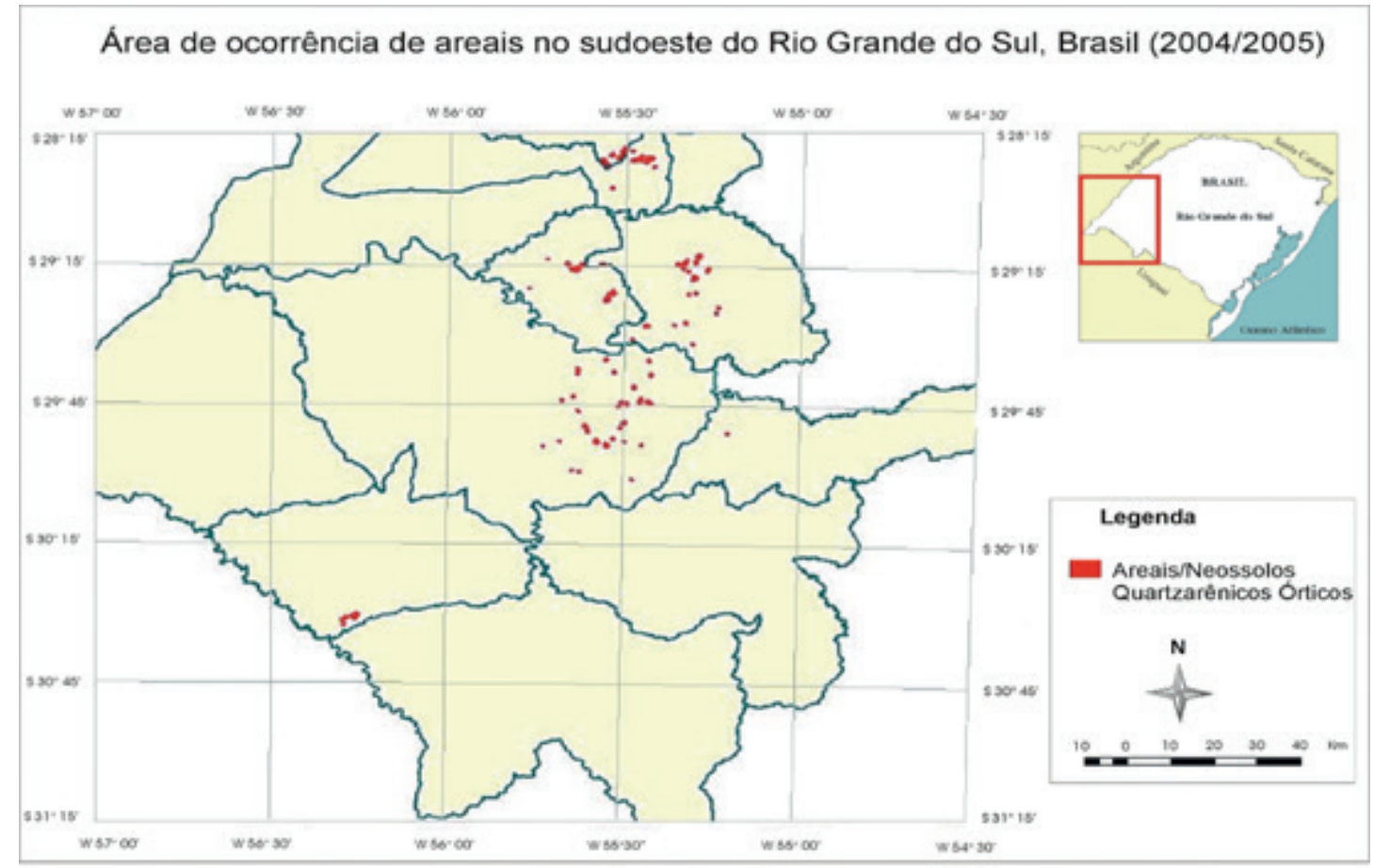

Fonte: Mapeamento elabcra atraves de imagans Landsat TM 5.
Projoto CNPq, Departamento de Geografia/VFRG, bolsista Clodis de O. Andrades Filho. Orientadora: Prof" Dra" Dirco Maria Antunos Suortogaray - Pcrto Alogre - 2005

Fonte: mapeamento elaborado através de imagens Landsat TM5. Projeto CNPq Ligado ao Departamento de Geografia da UFRGS. Bolsista: Clódis de O. Andrades Filho. Orientadora: Profa. Dra. Dirce Maria Antunes Suertegaray (2005).

O Rio Grande do Sul, na sua porção sudoeste, apresenta um conjunto de áreas sem cobertura vegetal constituída visualmente, de extensas áreas de solos arenosos expostos, que se denominam areais e, por vezes, "arenales", considerando a toponímia local. As figuras 2 A e $2 \mathrm{~B}$ exemplificam areais. 
Figura 2A - Areal Morro da Panela, no Distrito do Areal, em Quaraí, RS. Figura 2B Areal da localidade de Esquina, em São Francisco de Assis, RS

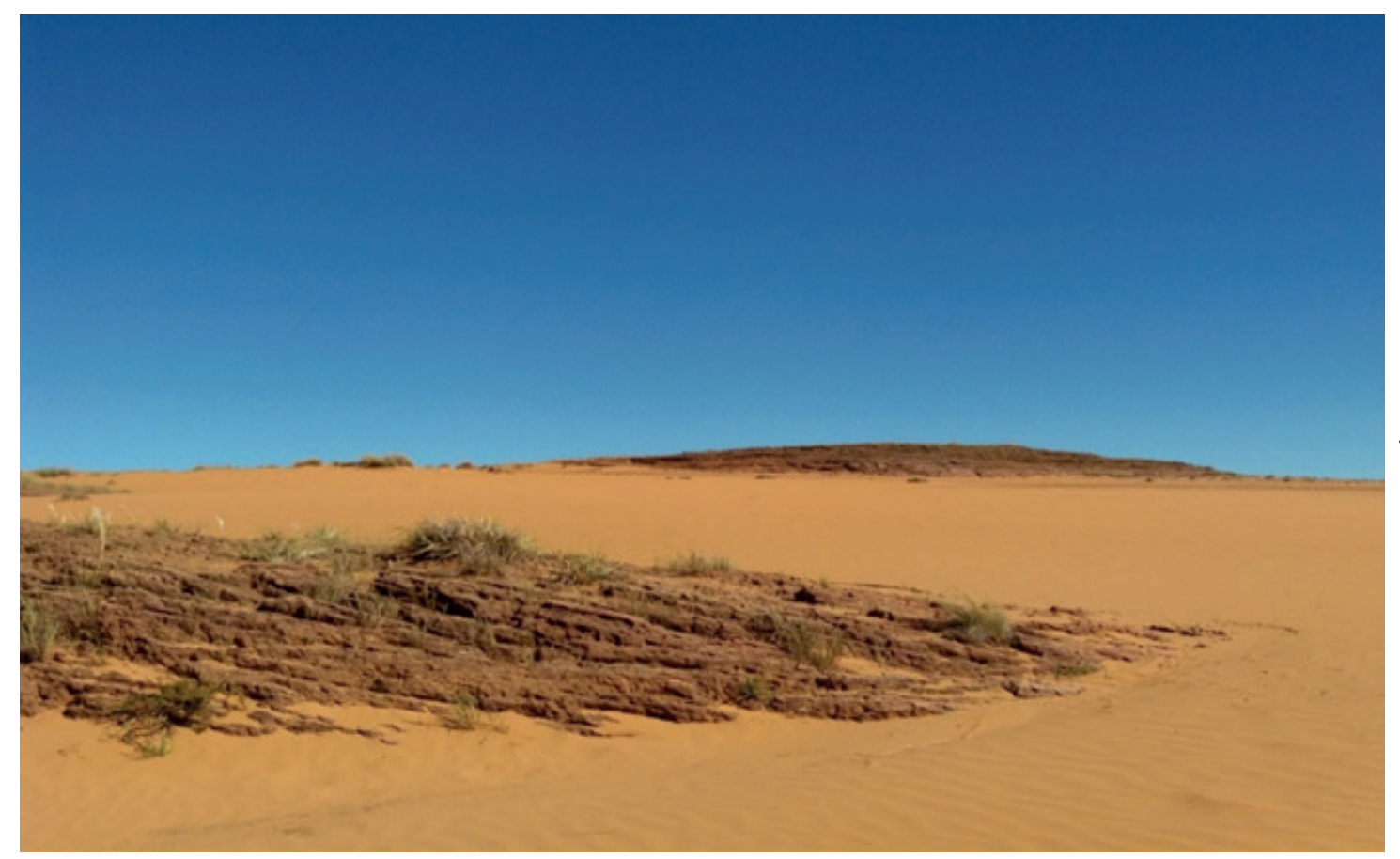

A

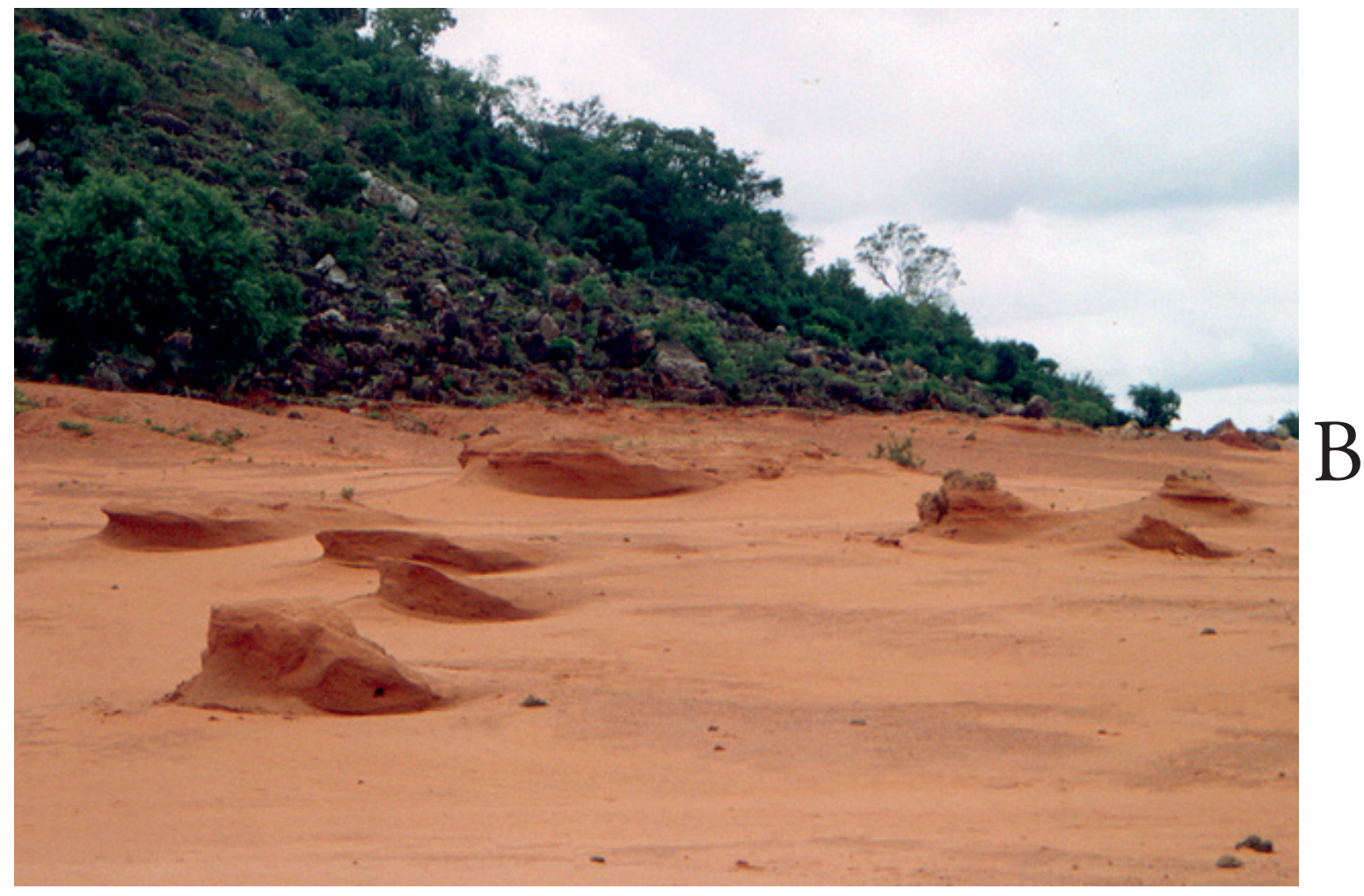

Fonte: a) foto de Dirce Suertegaray (2017), b) foto acervo do grupo de pesquisa Arenização/Desertificação questões ambientais, vinculado ao CNPq. (2008) 
Para entender a gênese dos areais, inicia-se indicando o substrato da área de ocorrência dessas feiçóes. No ano de 1987, toda a área de ocorrência de areais era mapeada como Formação Botucatu. Atualmente, um novo mapeamento foi elaborado e foi definida outra formação, em particular na área que se vincula à Planície Central do Rio Grande do Sul. Portanto, são caracterizadas duas formaçóes geológicas: Formação Botucatu, neste caso constituindo substrato dos areais em Quaraí; e a Formação Guará, presente nos municípios mais ao Norte, nos quais ocorrem areais, a exemplo do município de São Francisco de Assis. As fi guras 3A e 3B exemplificam essas formaçóes.

Este substrato não necessariamente explica a gênese dos areais. Sobre eles tem-se depósitos arenosos ou arenoargilosos friáveis e, portanto, susceptíveis à formaçáo de areais. Estes depósitos foram caracterizados por Suertegaray (1987) como unidade A, aqui denominados de Unidade Cati; e unidade B, aqui denominados de unidade Areal, e estấo presentes nas Figuras 4A e 4B.

Os areais ocorrem, predominantemente, na unidade B (Unidade Areal). Esta se caracteriza pela dominância de sedimentos arenosos, acima de $90 \%$, de areia média, constituindose de depósitos altamente suscetíveis à erosão. Agronomicamente, são classificados como solos Neossolos quartzarênicos órticos. 
Figura 3A - Formação Botucatu, com afloramento do substrato em areal de Quaraí, RS. Figura 3B - Formação Guará, com voçoroca, na Estrada São Francisco de Assis, município de Manoel Viana, RS.

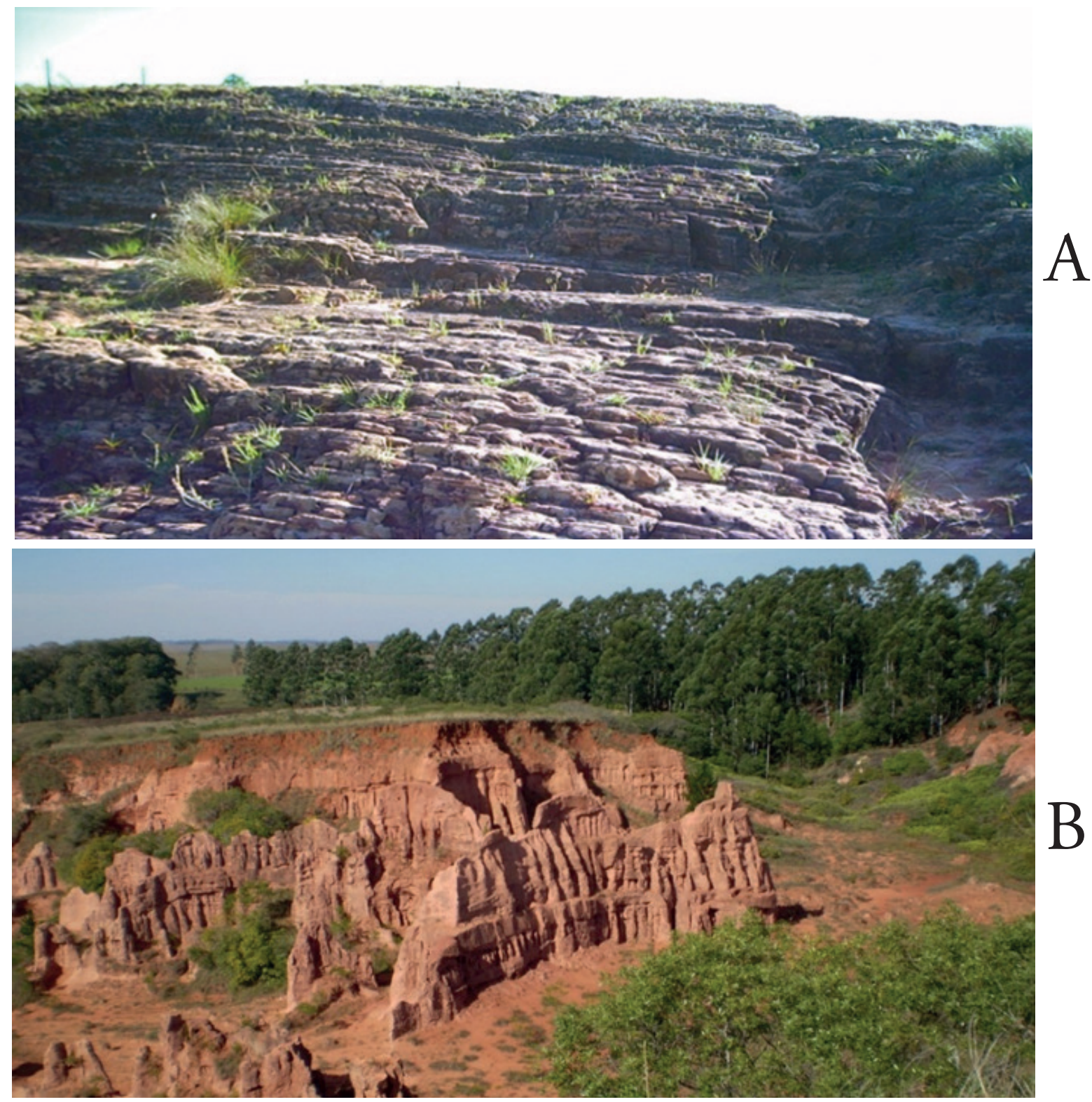

Fonte: fotos de a) Dirce Suertegaray (2015), b) Dimas Peixinho (2008) 
Figura 4A - Perfil da formação superficial na Unidade A (Cati), na encosta da BR295, município de Quaraí, RS. Figura 4B - Formação superficial na unidade B (Areal), na região dos Areais, município de Quarai, RS.

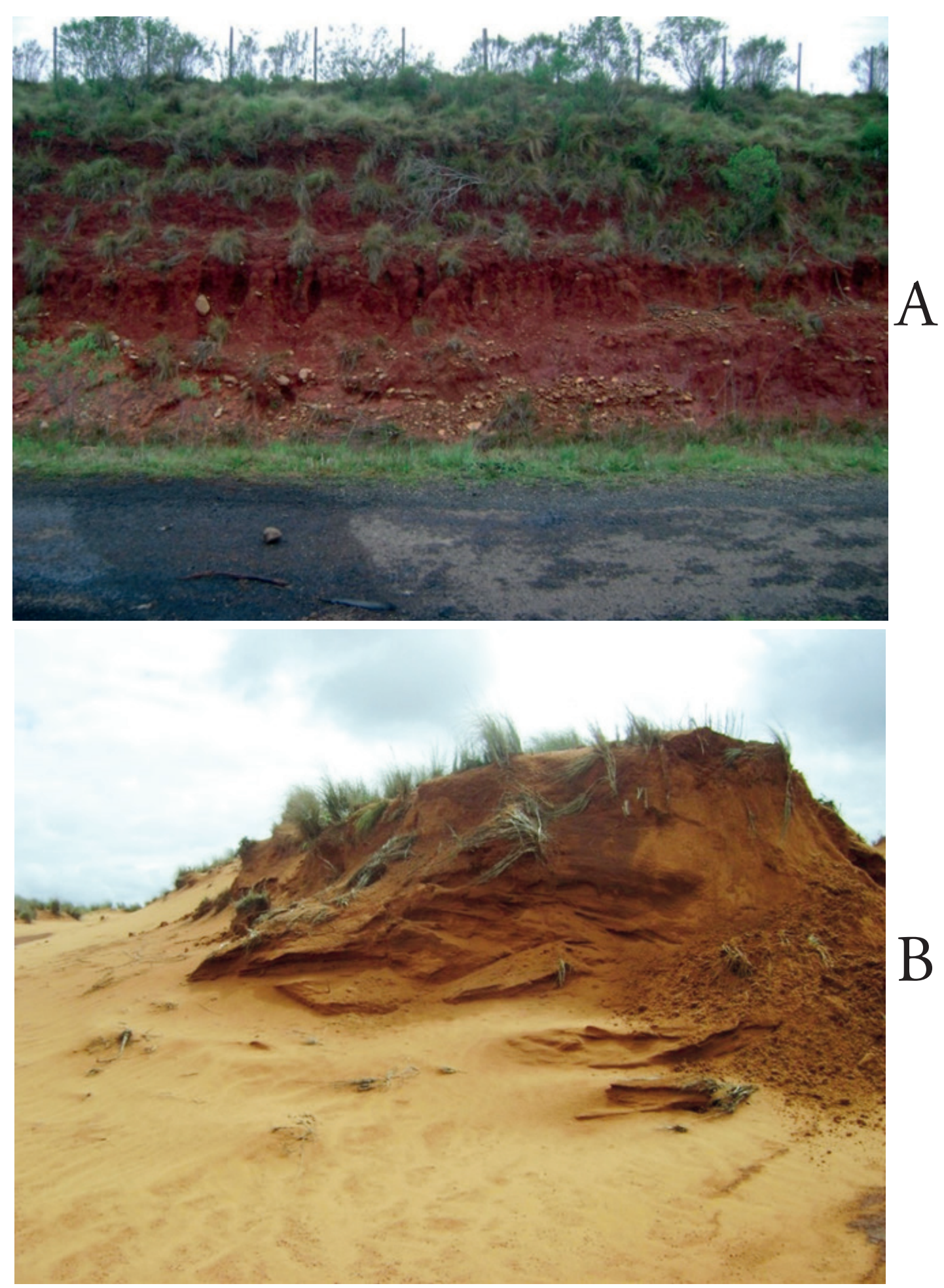

Fonte: a) e b) fotos de Ibrahim Soares (2015) 


\section{A ORIGEM DAS FORMAS AREAIS, UMA CONDIÇÁO NATURAL OU ANTROPOGÊNICA?}

Suertegaray (1987), a partir de relatos históricos resgatados, demonstrou que a regiáo de ocorrência de areais já apresentava estas formas, pelo menos desde a época em que se iniciou a colonização luso-espanhola, como pode ser constatado na descrição feita por AvéLallemant (1980 apud SUERTEGARAY, 1987) em seu relato de viagem por esta região:

"A lua um pouco velada, deitava um clarão turvo sobre a região. Subitamente, em torno de nós tudo parecia branco. Crer-se-ia viajar num campo de neve. Em volta, a areia pura, limpa, sem nenhuma vegetação, verdadeiro deserto africano embora de pouca extensão. Dava-me uma impressão particularmente melancólica. Viajamos juntos em silêncio" (AVÉ-LALLEMANT, 1980, p. 322).

Por outro lado, dados provenientes da pesquisa arqueológica pré-histórica demonstram a existência de sítios arqueológicos instalados sobre estes areais. Estudos feitos por Bellanca (2001), por exemplo, indicam convivência de povos indígenas caçadores e coletores, coexistindo com os areais, durante o Holoceno, corroborando a tese de Milder (2000), que, segundo ele, constitui-se numa relevante contribuiçáo para o entendimento da formaçáo dos areais dessa regiáo.

Os estudos arqueológicos, os achados encontrados em decorrência da decapagem por erosão hídrica e/ou eólica (BELLANCA, 2001) revelaram a presença de líticos e de material cerâmico que caracterizam diferentes povos indígenas habitantes da região. Conforme identificaçáo e datação desse material, conviveram com os areais povos caçadores ancestrais e, mais recentemente, anteriormente à colonização luso-portuguesa, charruas, minuanos e guaranis. A Figura 5 registra a presença do sítio arqueológico no Morro da Panela, acrescida da ilustração dos líticos encontrados, desde a pedra lascada até a cerâmica. 
Figura 5 - Sitio Arqueológico presente no Areal Morro da Panela/Figueira, em Quaraí, RS.

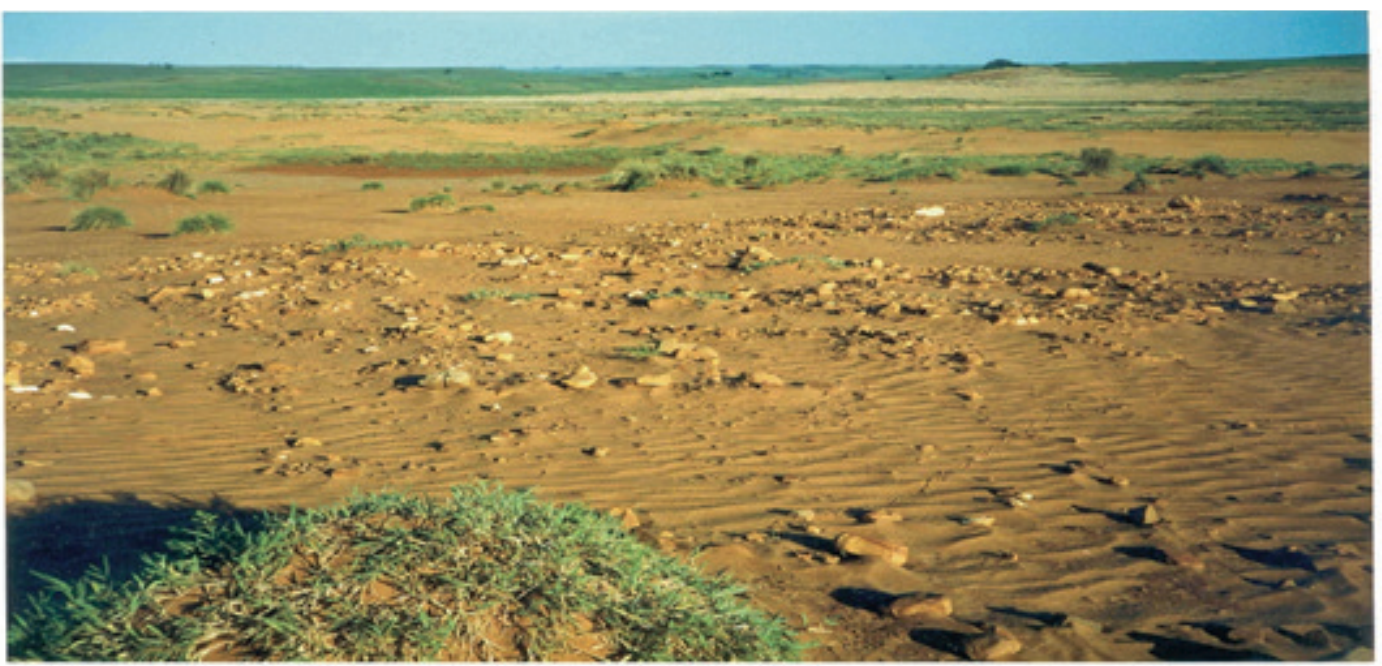

Figura 2: Fotografia do sitio e ilustração dos líticos.

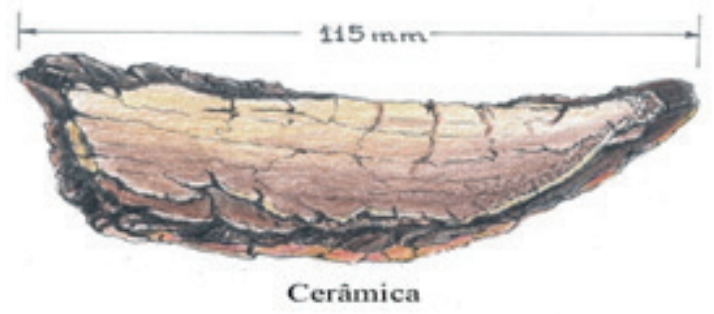

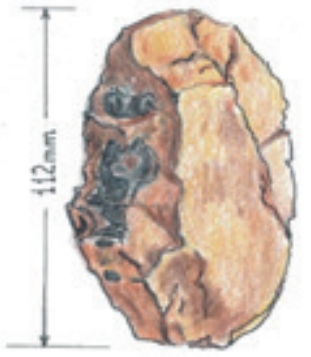

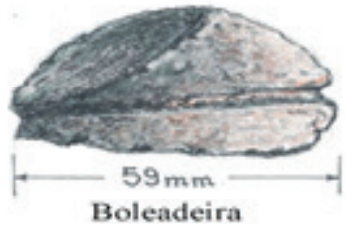

Boleadeira
Litico 1

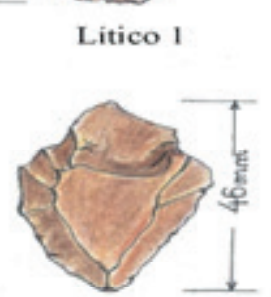

Litico 2

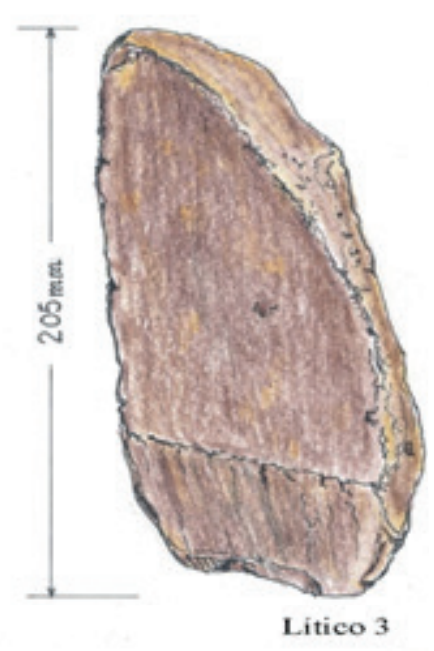

Fotografia e Desenho: Bellanca, 2002.

Fonte: Bellanca, 2002

A informação arqueológica indicando a copresença de indígenas em áreas com formação de areais corrobora os estudos feitos por Suertegaray (2017), que indicavam que essas feiçóes têm gênese natural, na medida em que a organização social desses grupos e as práticas associadas à coleta e à caça não sugerem uma possível associação antropogênica, pelo menos nos areais do município de Quaraí. Cabe, no entanto, observar que também em areais localizados em outras regióes é comum encontrar líticos, embora ainda não estudados sistematicamente.

Além do material arqueológico, estudos encaminhados no campo da biologia, em particular sobre a fauna e a flora do local, permitiram que indicadores biológicos fortalecessem a tese da origem natural dos areais. Trata-se do reconhecimento de um ortóptero camuflado (gafanhoto), descrito por Pires (2006), e constante na Figura 6. 
Figura 6 - Animal ortóptero, Família Ommexechidae, com camuflagem que o confunde com os sedimentos formadores de um areal, observado no Município de Manoel Viana, RS, em 2006. Essa conectividade da camuflagem do seu exoesqueleto, imitando as texturas das partículas dos sedimentos dos areais, revela a integração e complexidade dessas paisagens.

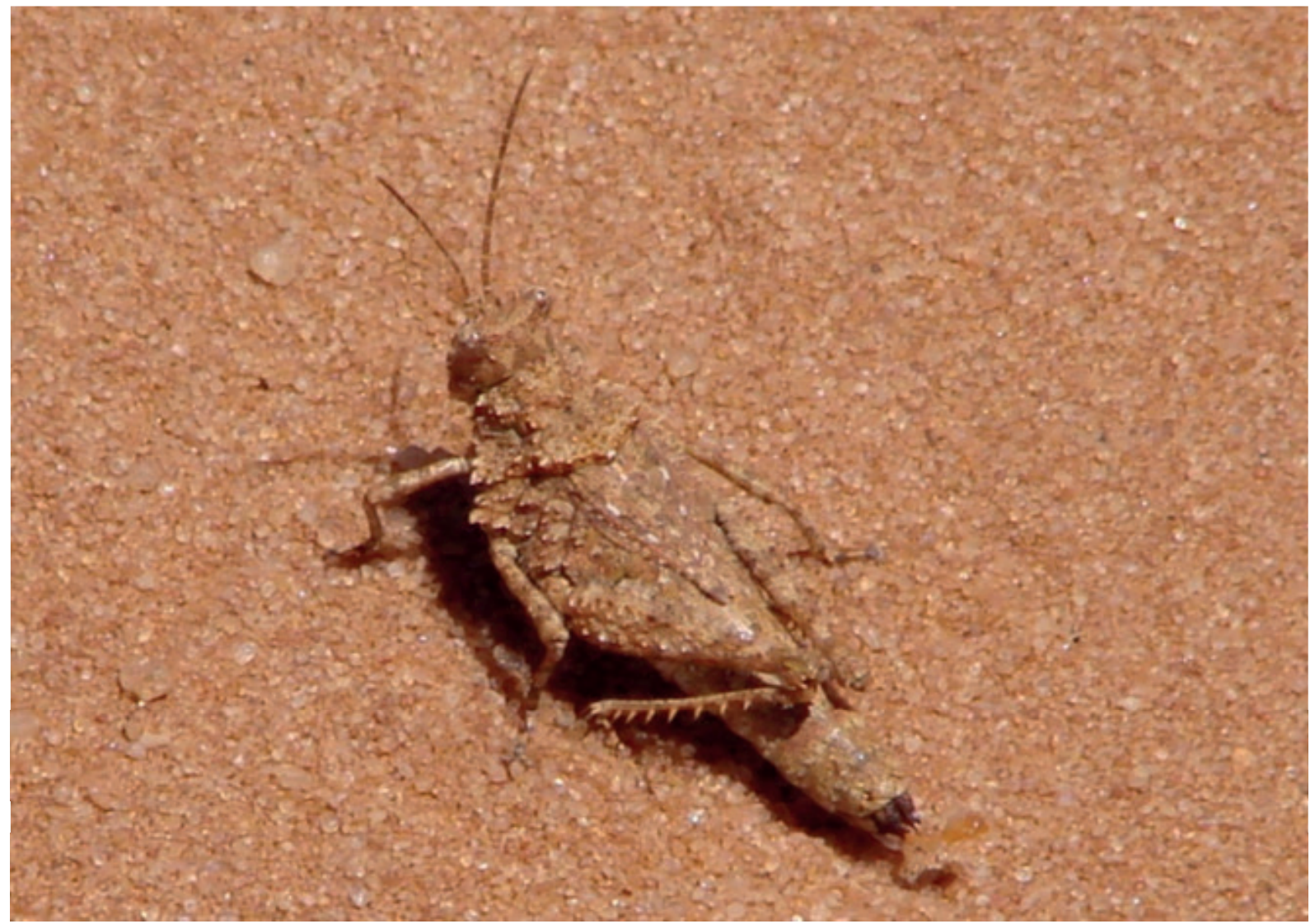

Fonte: Luís Alberto Pires (2006).

Os processos associados à gênese dos areais, considerando a dinâmica da natureza, estão vinculados à dinâmica hídrica superficial e de subsuperfície, além da ação do vento. Os estudos de Suertegaray (1987) indicaram que a dinâmica dos areais decorria do escoamento superficial concentrado, dando origem a ravinas e a voçorocas. Esta dinâmica é comum em rampas localizadas à base de relevos-testemunhos presentes na região. $\mathrm{O}$ processo de erosáo, mais intenso em período de chuvas torrenciais, promove a erosáo e o transporte de areias constituintes das formaçóes superficiais que sobrepóe o substrato arenítico. Estas são carreadas e depositadas à jusante, na forma de depósito em leque. Na continuidade, esses processos coalescem (se agrupam), ao mesmo tempo que ravinas e/ou voçorocas erodem lateral ou remontante. Essa dinâmica, em conjunto, dá origem aos areais. A Figura 7 exemplifica essa dinâmica. Nela, pode ser observado, ao fundo, um areal consolidado; à frente, um conjunto de ravinas paralelas entre si, que tenderão à constituição de um areal. 
Figura 7 - Areal e processos de arenização, no município de Maçambará, RS.

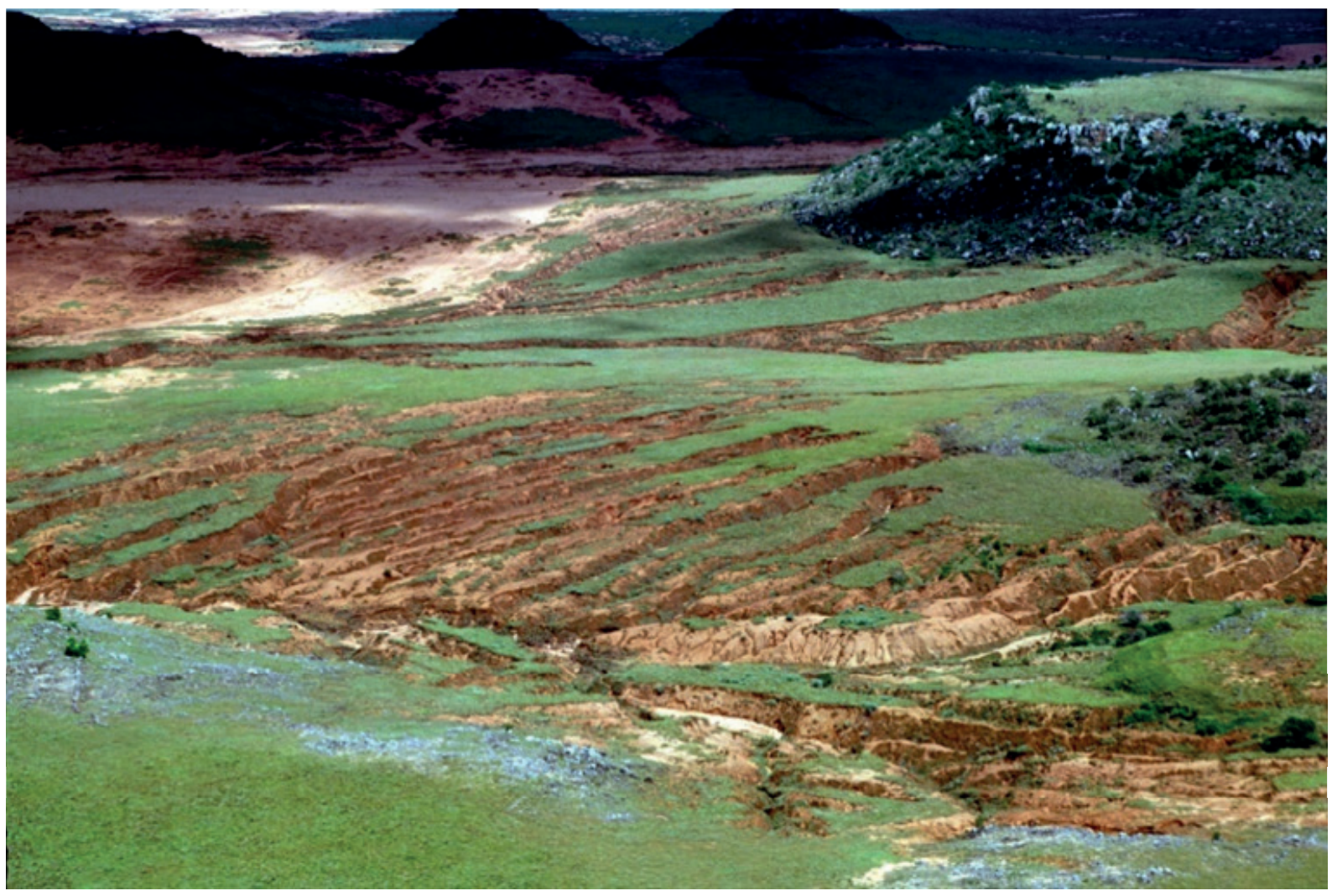

Fonte: Suertegaray et al. (2001).

A Figura 8 indica o processo de arenização em sua condição inicial, quando o escoamento superficial concentrado se configura na forma de ravinas. 
Figura 8 - Área em fase inicial de processo de arenização (constituição de ravinas). Morro da Esquina, São Francisco de Assis, RS.

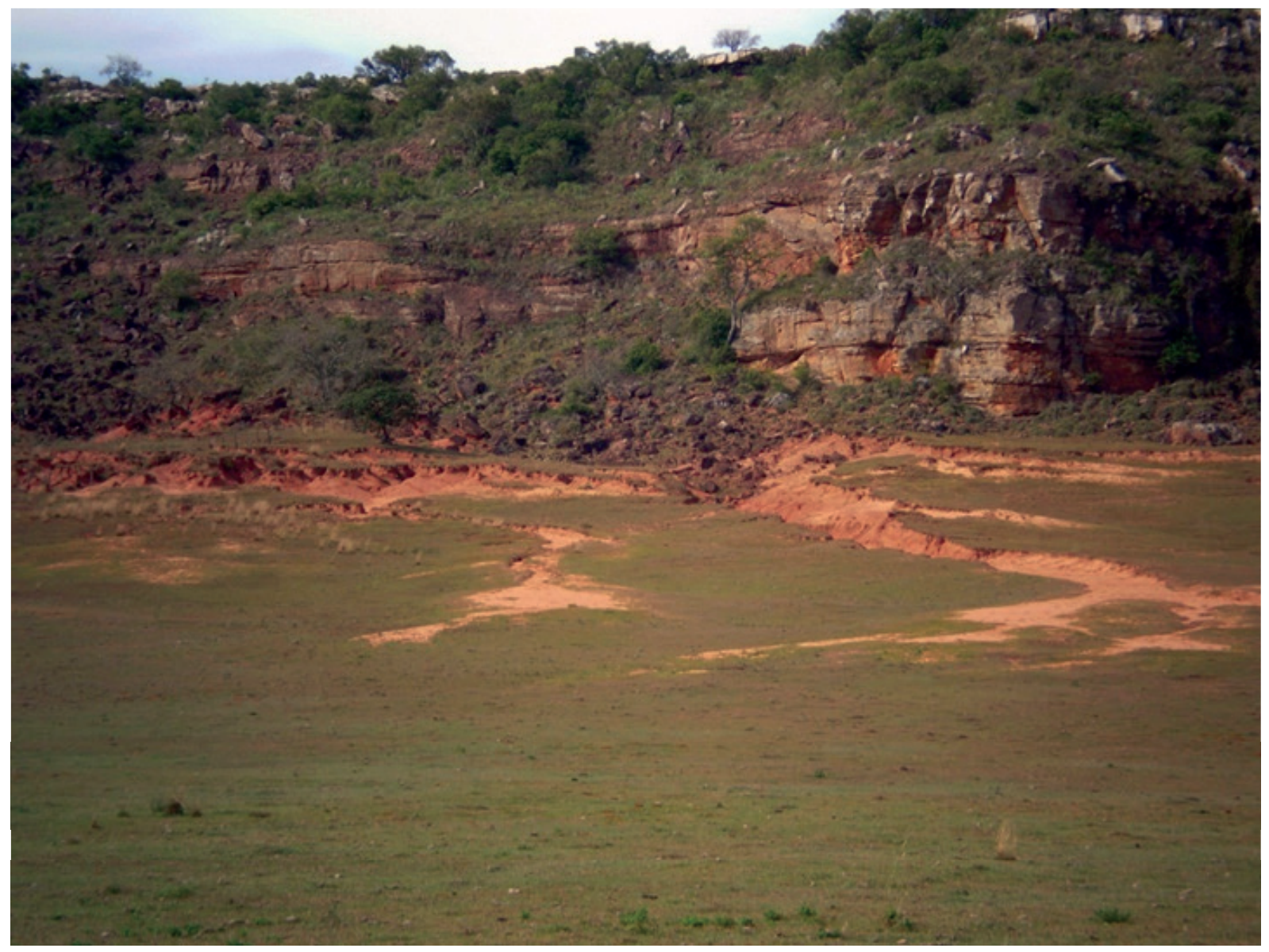

Fonte: Suertegaray et al. (2001)

A Figura 9 apresenta o processo de arenização em etapa de constituição de areais. À jusante, o areal constitui a expressão do processo de arenização associado à dinâmica hídrica e eólica. A deflação, após a constituição de um areal, é, da mesma forma, um processo atuante na remoção de areia, favorecendo a expansão dos areais nas mais diferentes direçóes. 
Figura 9 - Areal em rampa. Morro da Esquina, São Francisco de Assis, RS.

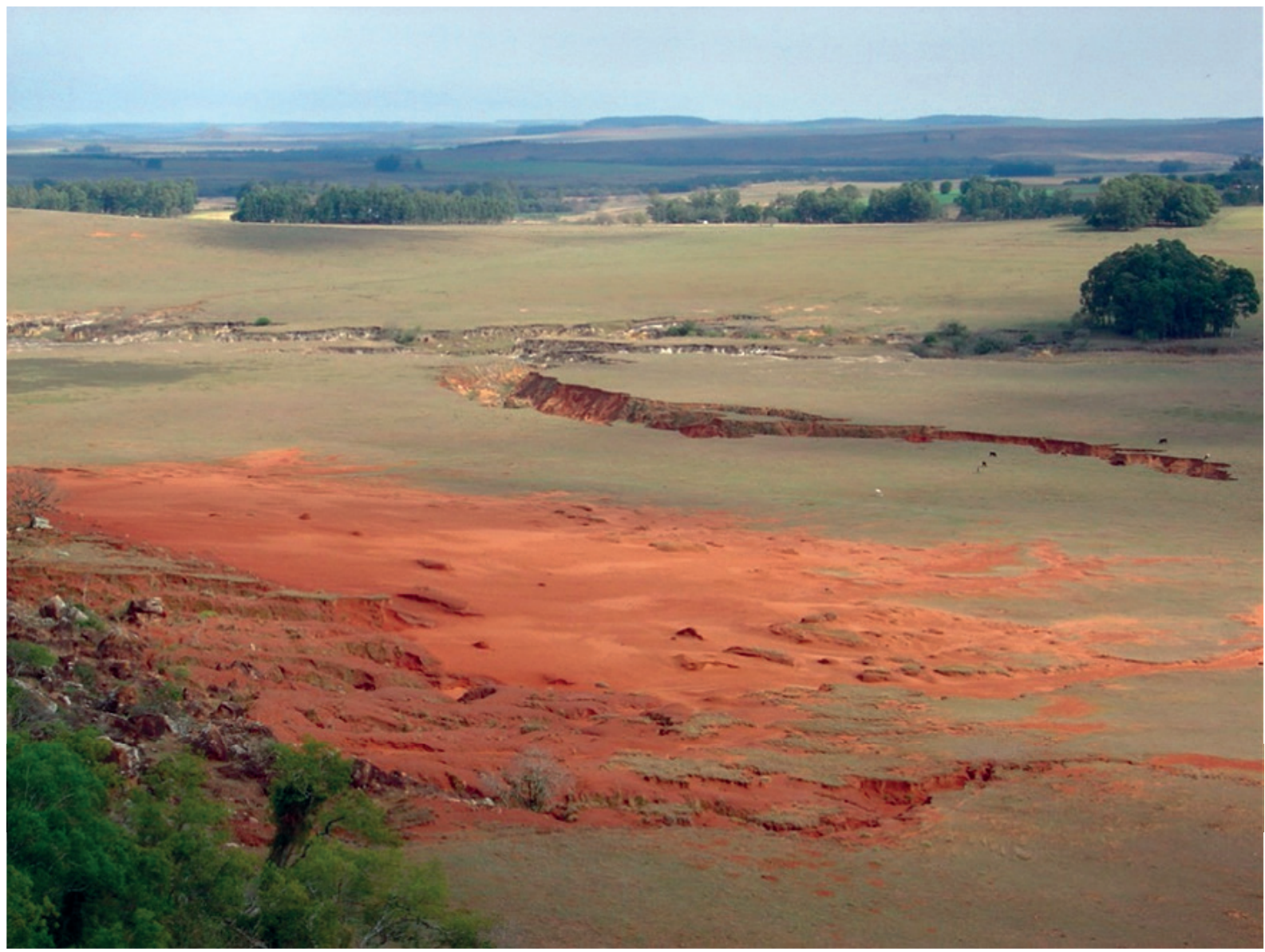

Fonte: acervo do grupo de pesquisa Arenização/Desertificação - questões ambientais, vinculado ao CNPq (2008).

Uma terceira fase, com uma particularidade, é observável na Figura 10A. Aí, tem-se a constituição de um areal de grande porte, no qual ficam evidenciados sua expansão e, consequentemente, o assoreamento dos arroios (sangas) em sua proximidade. $\mathrm{O}$ assoreamento do canal fluvial, além de ampliar a área de areia exposta, promove modificação no fluxo da água, passando de um fluxo concentrado para um fluxo intermitente ou anastomosado. $\mathrm{Na}$ mesma Figura 10A é observável, em detalhe, o leito de ravinas em fase de assoreamento pelo transporte da areia, seja pela água, seja pelo vento. Concomitantemente, o canal é preenchido pela areia depositada pelo material de montante ou de entorno. Trata-se de um processo de entalhe e de preenchimento, que vem sendo associado a uma reativaçáo da paleodrenagem. A Figura 10B exemplifica o processo de assoreamento no interior do canal de uma voçoroca, demonstrando que o aporte de material no período de chuvas, em especial as torrenciais, é maior do que a capacidade de fluxo, fazendo com que parte do material seja transportado e depositado ao longo do percurso. 
Figura 10A - Areal em expansão e assoreamento de canais fluviais de pequeno porte (Maçambará - RS, São Francisco de Assis, RS - 2008). Figura 10B - Detalhe de uma voçoroca com preenchimento de canal pelo aporte de material arenoso depositado na medida em que diminui o fluxo de água superficial (Morro da Esquina, São Francisco de Assis, RS 2008.
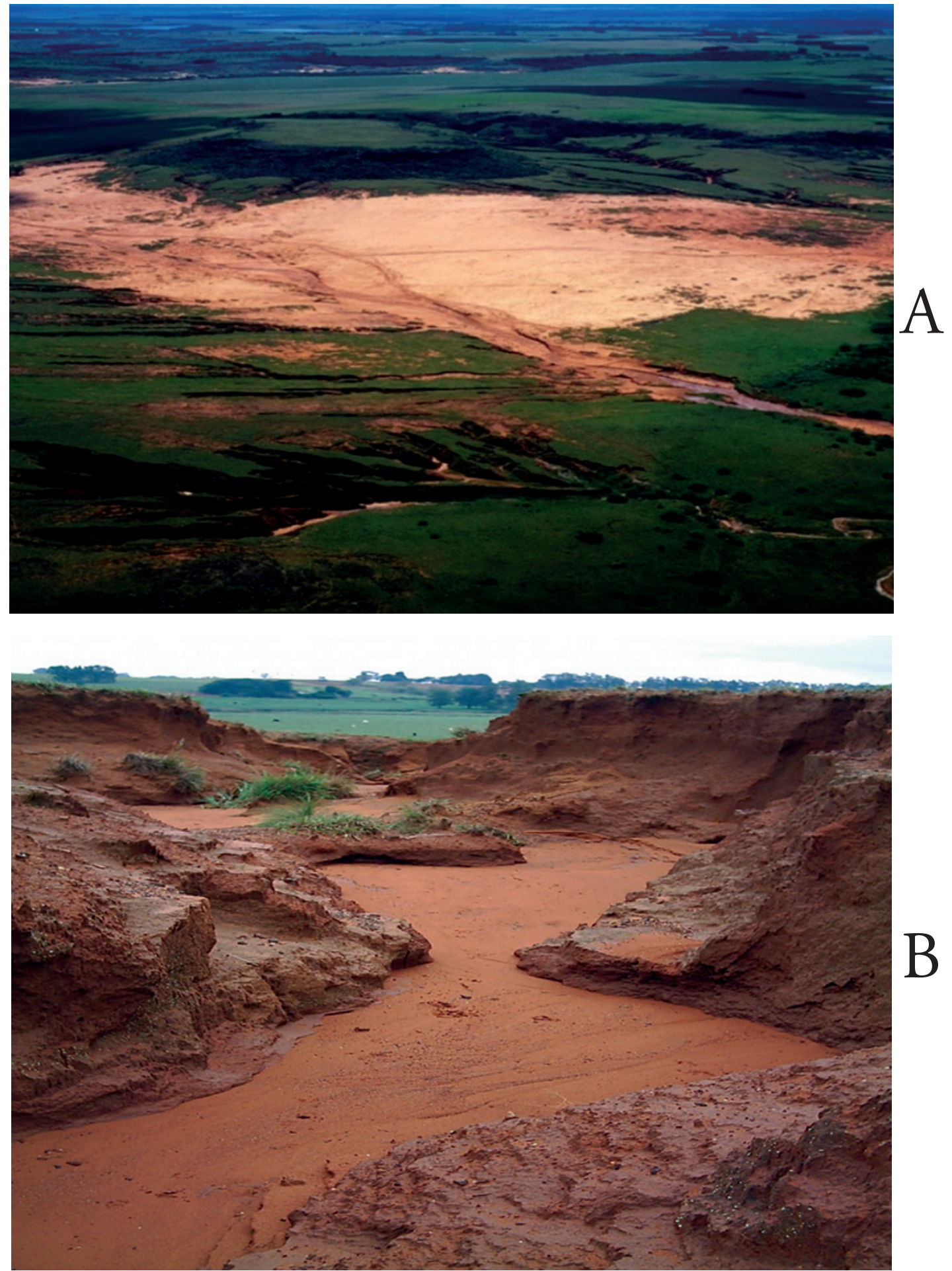

$\mathrm{B}$

Fonte: a) Fonte: Suertegaray et al (2001), b) foto do grupo de pesquisa Arenização/Desertificação - questões ambientais, vinculado ao CNPq. (2008) 
A par de processos erosivos atuantes sobre esses sedimentos que constituem os areais, no campo interdisciplinar outras questóes se revelam. Uma delas será tratada no próximo item.

\section{HÁ VIDA NOS AREAIS. HÁ BIODIVERSIDADE?}

Esta foi uma questão com a qual se preocupou Pires (2008). Biólogo de formação, buscou, através de trabalho de campo, registrar as espécies vegetais e os animais que habitam os areais. A seguir, apresenta-se um conjunto de imagens captadas, ao longo de sua trajetória de campo, que, entre tantas outras capturas, revelam a existência de vida nos areais. As descriçôes de cada imagem estão contidas nas legendas. Observa-se que muitas das espécies presente nos areais são indicadores biológicos de ambientes mais secos de um passado recente. Seguem as Figuras 11, 12, 13, 14, 15, 16, 17 e 18, com legendas elaboradas pelo autor.

Figura 11 - Eugenia pitanga (O. Berg.) Nied (Myrtaceae), com frutos do tipo drupa, folhas coriáceas e sistema radicular profundo, típicas características para ambiente propício ao ressecamento climático constante e a fatores edáficos locais restritivos.

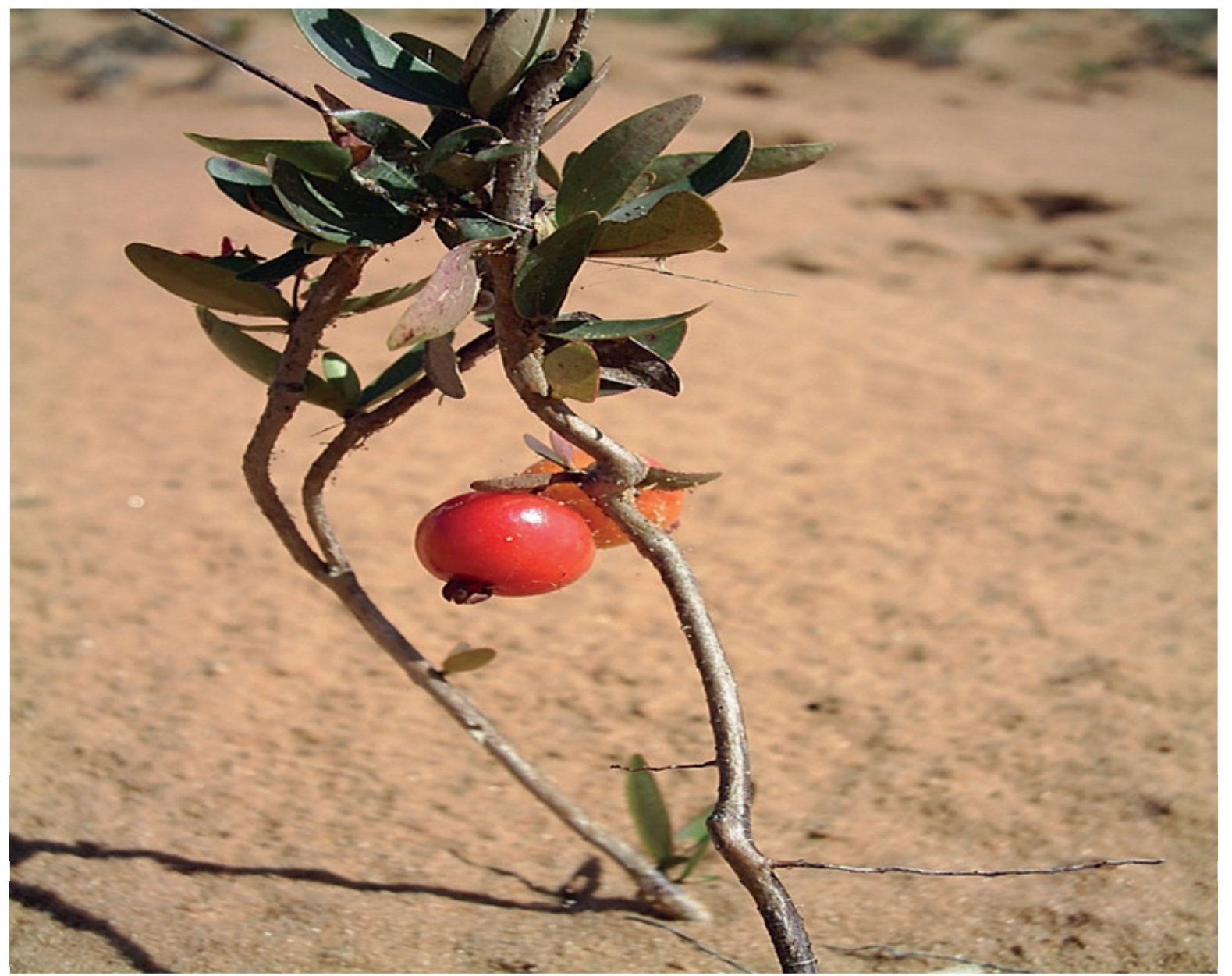

Fonte: Luís Alberto Pires (2007) 
Figura 12 - Inseto com intensa camuflagem com o substrato típico de um areal, da Ordem dos ORTÓPTEROS e da Família Ommexechidae. (Fazenda Santo Antão, no Município de Alegrete).

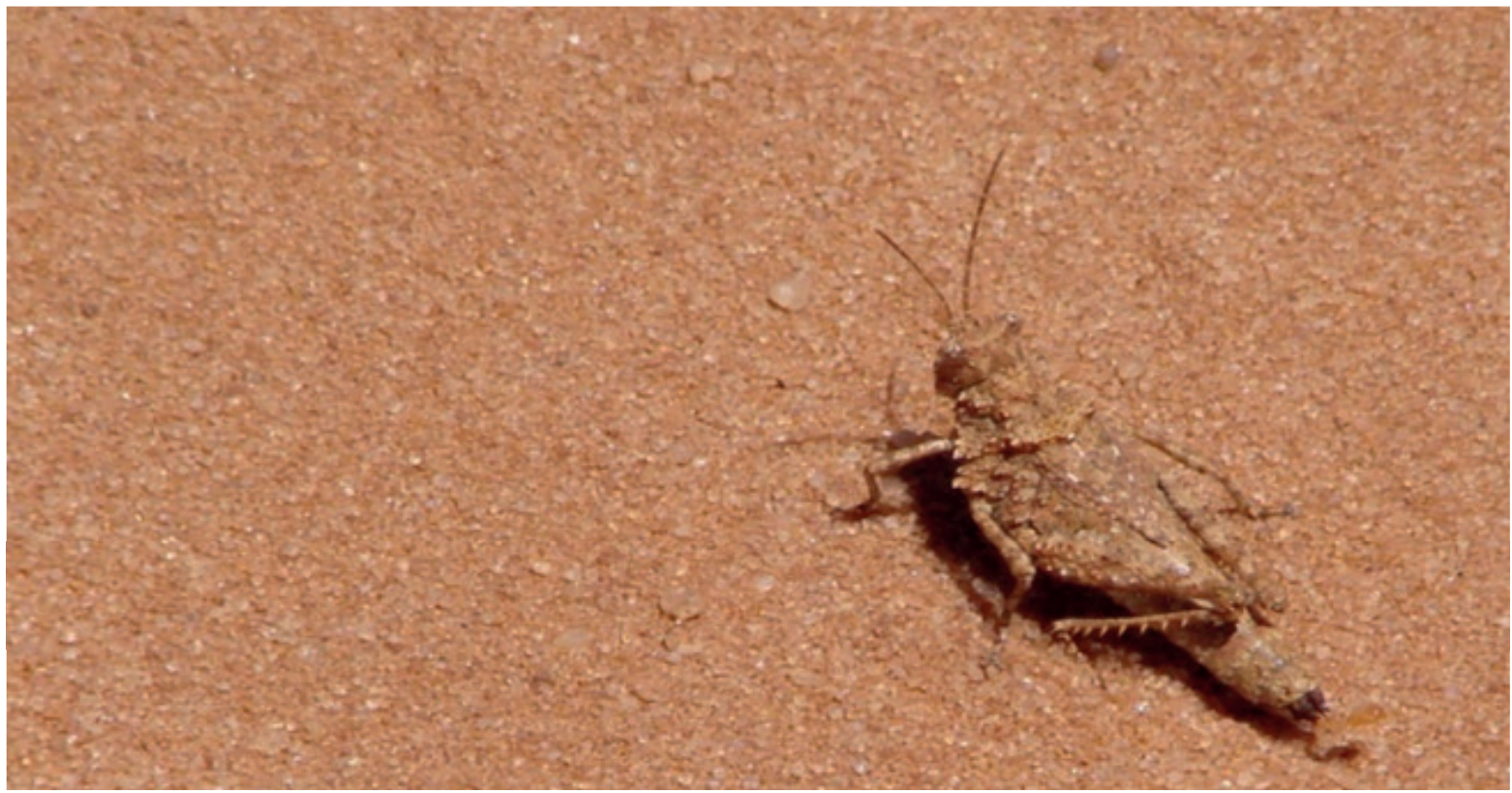

Fonte: Luís Alberto Pires da Silva (2007)

Figura 13 - Imagem dos "olhos" de formigas saúvas, de gênero Atta; à esquerda, rotina de transposrte de material vegetal, sendo encaminhado às panelas de fermentação, por membros da casta de "operárias", observadas por membros da casta de "soldados" (Areal da Fazenda Santo Antão, em Alegrete, RS) 2006 e 2007.

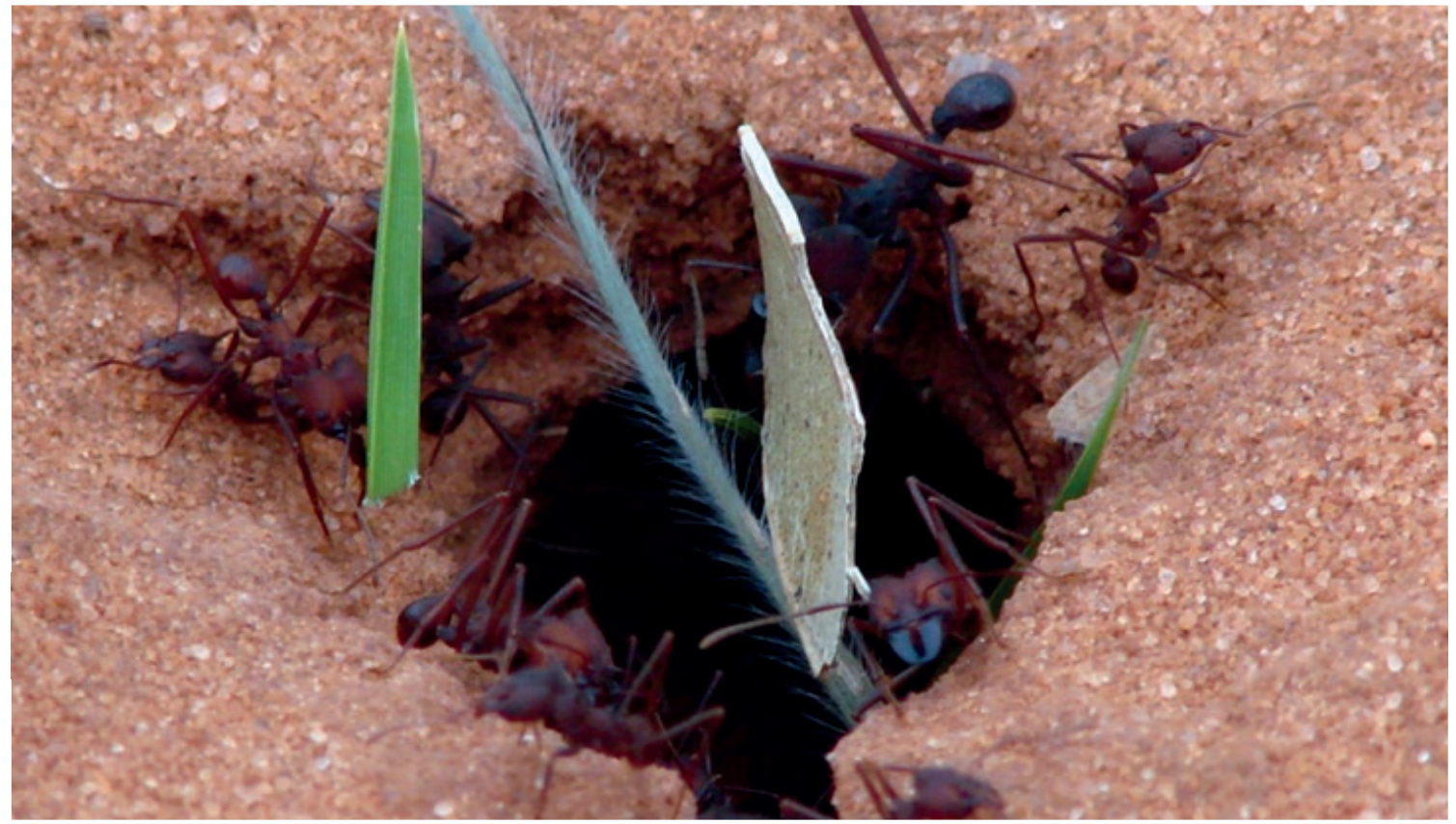

Fonte: Luís Alberto Pires da Silva (2007) 
Figura 14 - Lacertídeo no areal do Cerro do Tigre, no Município de Manoel Viana, RS (2007).

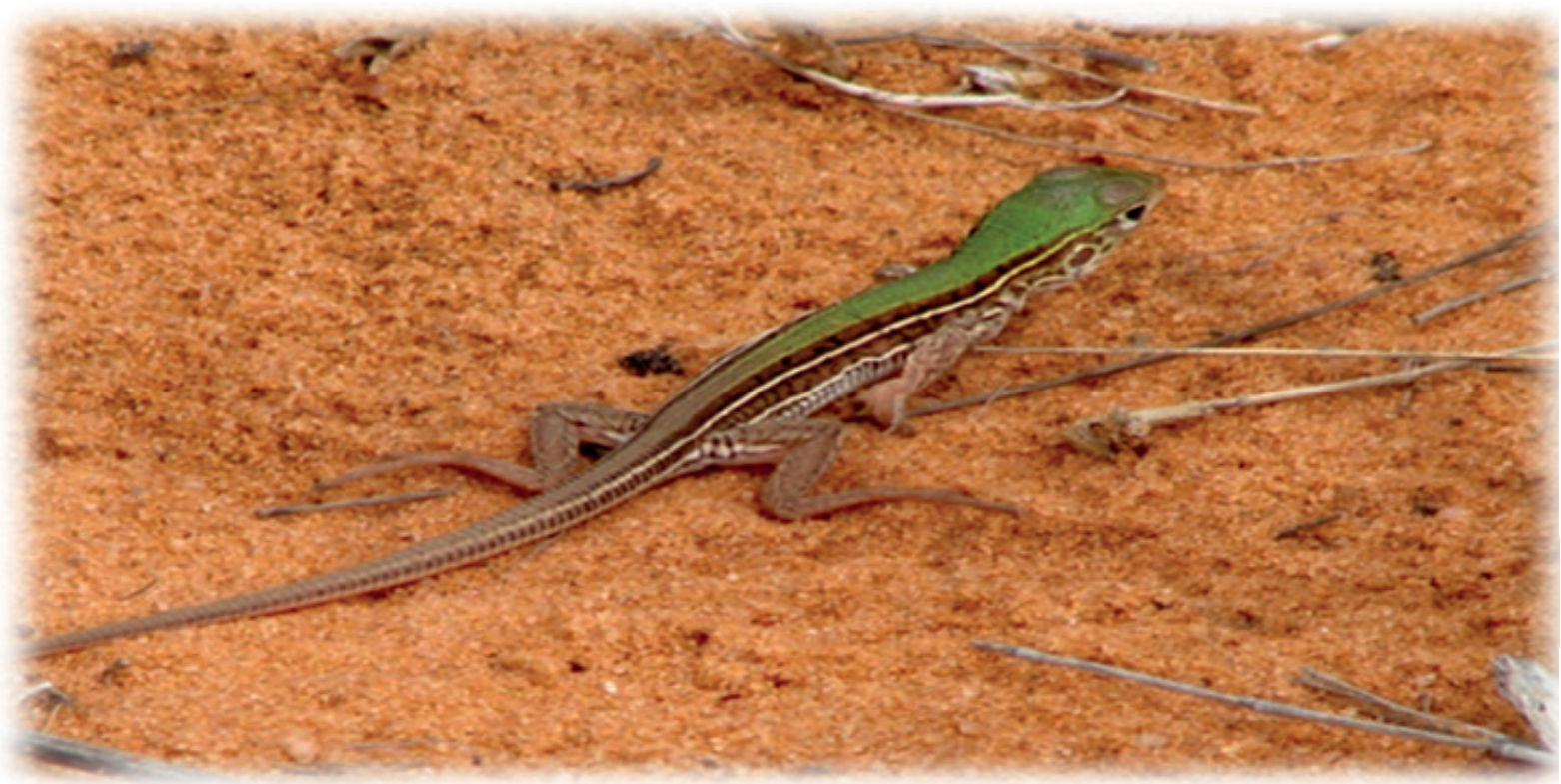

Fonte: Luís Alberto Pires da Silva (2007)

Figura 15 - Cactácea em flor (Parodia ottomis), no Cerro da Esquina, em São Francisco de Assis, em 02 de novembro de 2006.

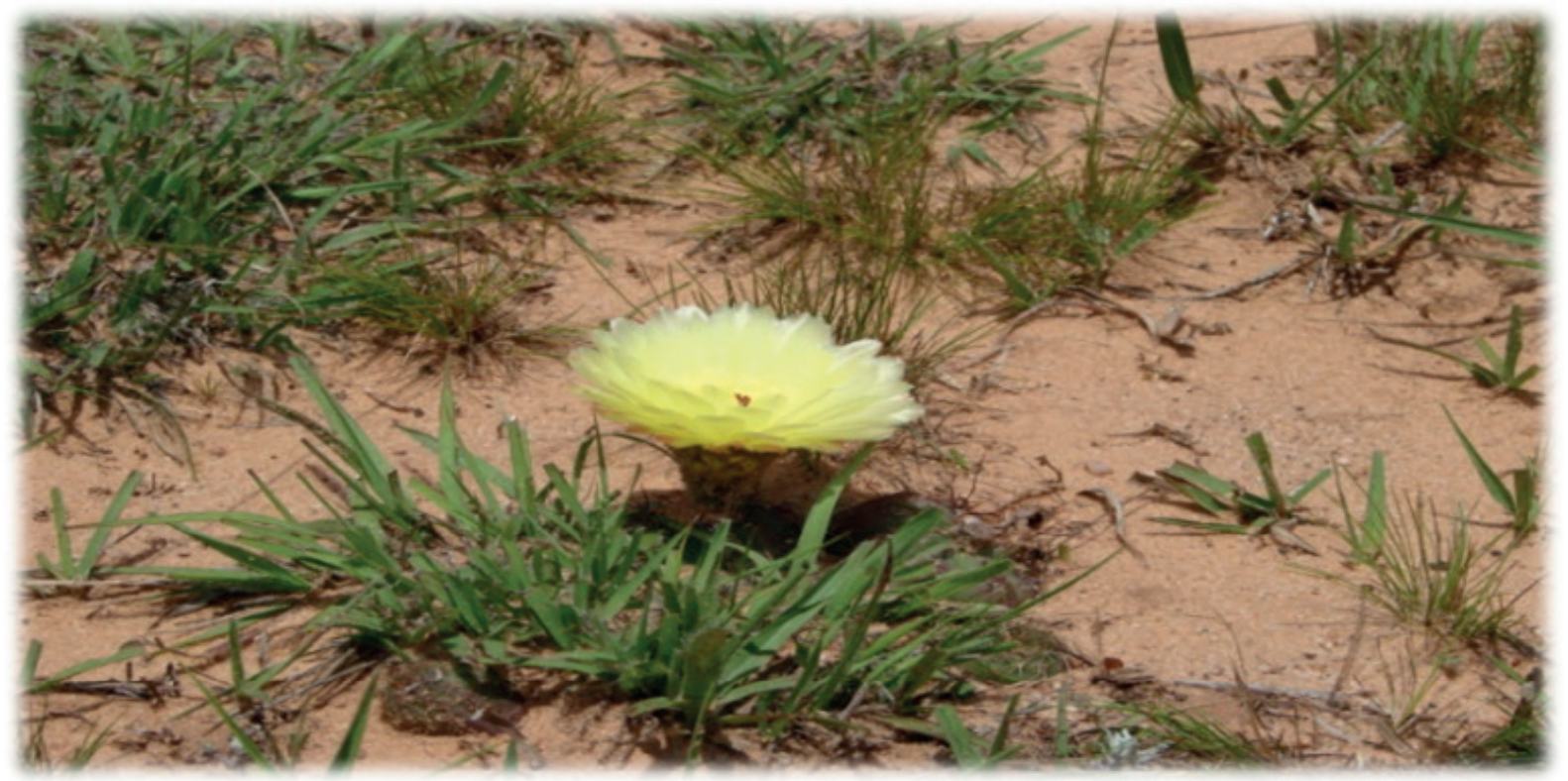

Fonte: Luís Alberto Pires da Silva (2006) 
Figura 16 - Planta com intensa pilosidade na lâmina foliar, típica característica de adaptações de espécies ao ressecamento climático constante (Areal da Fazenda Santo Antão, município de Alegrete) em 2006.

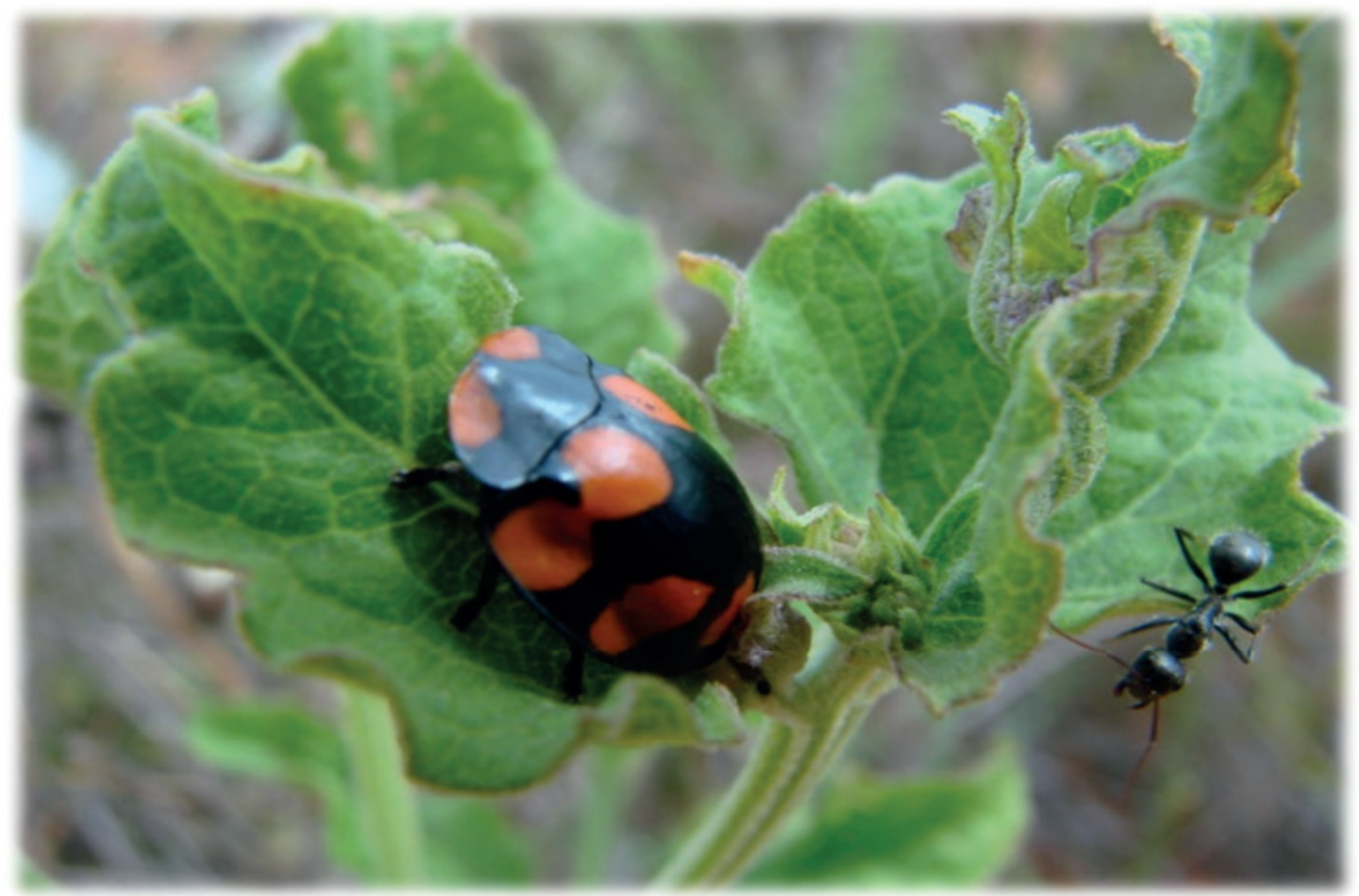

Fonte: Luís Alberto Pires da Silva (2006)

Figura 17 - Vegetal com estrutura caulinar intumescida, continuada sob a forma xilopódio, armazenador de nutrientes e de água. Fazenda Cerro do Tigre, em Alegrete, 2006.

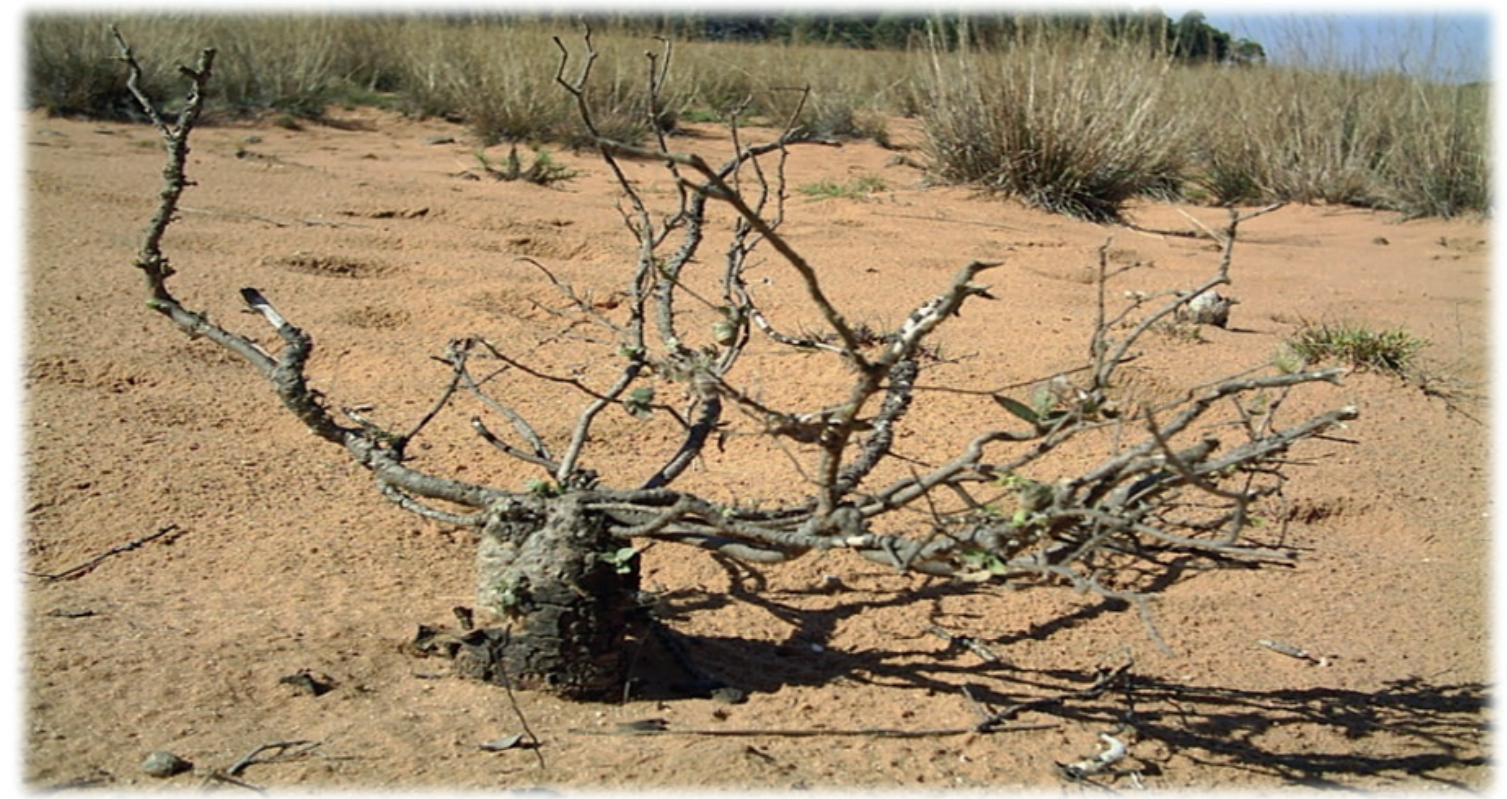

Fonte: Luís Alberto Pires da Silva (2006) 
Figura 18 - Espécie de cactácea Echinopsis oxygona (link) Zucc., no Areal do Cerro da Esquina 17/07/2007.

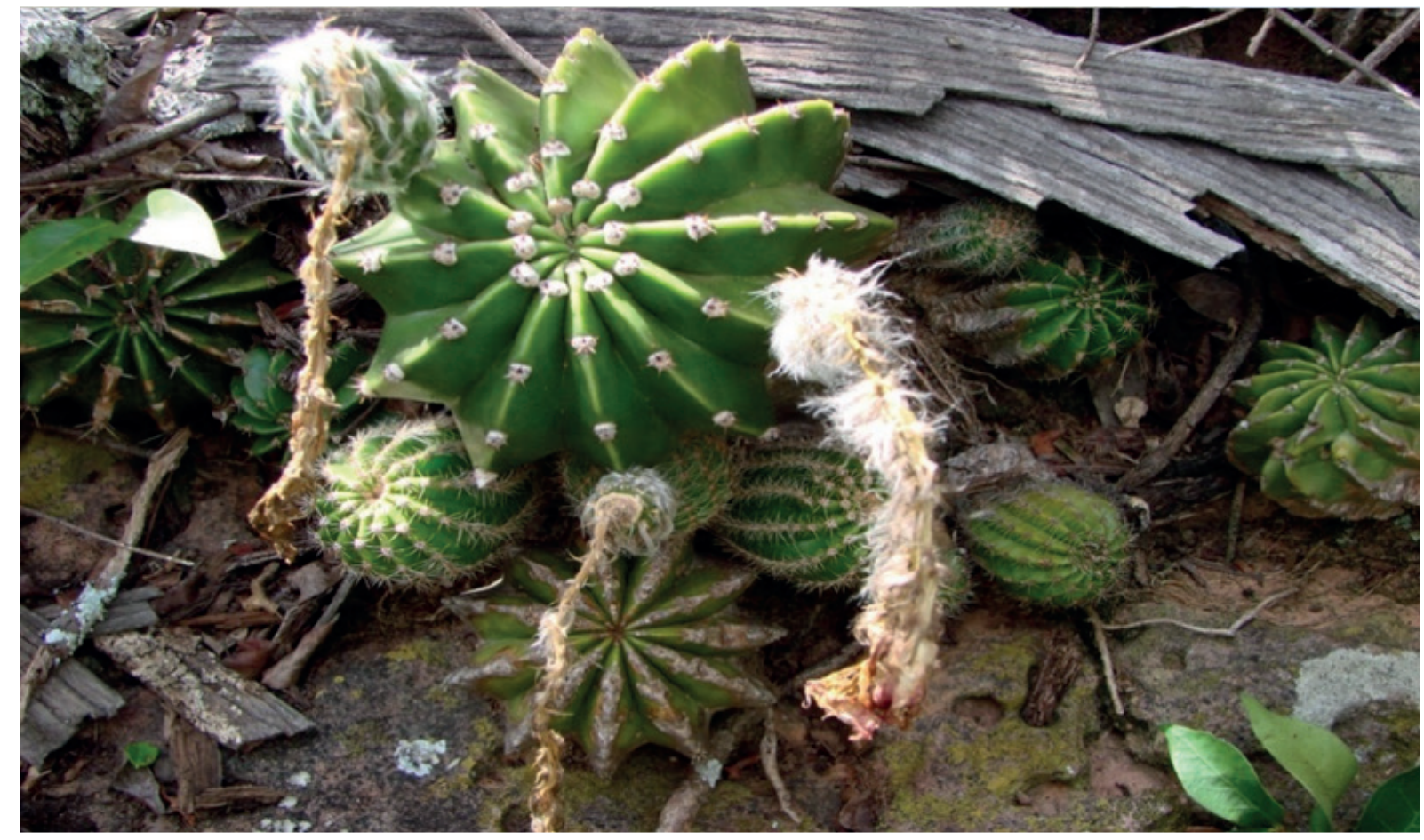

Fonte: Luís Alberto Pires da Silva (2007)

Para explicitar o significado dessa contribuição, no que tange à gênese natural dos areais, transcrevemos a interpretação feita por Pires (2008), ao se referir, especificamente, ao gafanhoto (Figura 12) deste breve catálogo de imagens referentes à vida nos areais:

Ao buscar o entendimento do conjunto de organismo que se vale das manchas de areias, como parte do seu nicho ecológico, não consigo me desvencilhar da idéia(sic) dessa porção, unidade da paisagem do Bioma Pampa, como uma Janela temporal. Ao olhar atentamente ao ortóptero da figura 25 e buscar uma justificativa para uma camuflagem com tamanha afinidade com o substrato arenítico, fica impossível relacionar essa façanha à evolução dessa espécie em congruência com o ambiente que vive num espaço temporal recente. Esse, entre outras manifestações de vida encontradas nos areais, nos aproxima de uma janela do tempo que pode reproduzir parte das condições ambientais dominantes nessa região há milhares de anos antes do presente. Ao procurar descrever as sensações primeiras mobilizadas pela paisagem dos areais e percorrendo a sua fisionomia, nos vemos diante de um recorte temporal das condições biotípicas reinantes em tempos pretéritos. Somos espectadores privilegiados diante de uma janela, onde a paisagem se confunde no tempo. Materialmente ancorados no presente, nossa mente nos remete ao passado longínquo. Evidências no substrato da paisagem dos areais e os organismos vivos que a compõe, testemunham condições ambientais, singulares não sustentadas pelos dados climáticos atuais. 
Com o termo ecossistema testemunho procuro explicar a janela temporal aberta pela paisagem dos areais, que nos fornece vestígios de adaptações estruturais e fisiológicas da vida diante das restrições ambientais impostas em tempos pretéritos, mantendo o acoplamento biótopo $\leftrightarrow$ biocenose e testemunhado pelo ecossistema dos areais. O termo ecossistema testemunho surgiu em debates na cumplicidade do caminhar pelo areal, na propriedade do Senhor Anair Bem (município de São Francisco de Assis, RS), proposto pelo Prof. Dr. Roberto Verdum. Assimilado a minha percepção ansiosa, direcionei meus interesses em buscar de argumentos no sentido de auxiliar a legitimação desse testemunho. (PIRES, 2008, p. 117-118).

Esta leitura traz um novo olhar para os areais, permitindo refletir sobre o conceito de área degradada, difundido e utilizado ao longo de um tempo de pesquisa. Os indicadores biológicos, associados aos estudos de microclima (SILVA, 2009), revelam, conforme exposto abaixo, a complexidade no entendimento da gênese dos areais.

Em síntese, o que se revela neste estudo pode ser sumarizado nos seguintes tópicos:

A regiáo campestre do Rio Grande do Sul é interpretada de longa data como uma área com presença de vegetação de ambiente diferenciado do atual, ambiente árido frio associado ao Pleistoceno.

Parte da vegetação ainda presente nessa área é representativa de uma expansão proveniente do Monte (Bosque) Argentino, região seca de dispersão.

Em que pese à expansão das espécies de clima úmido, estas se apresentam acopladas às espécies de ambiente árido que, em alguns casos, mantém-se em nichos, constituindo minirefúgios(sic). Estes são favorecidos pelos tipos de substratos: arenoso, relativamente seco e quente, devido à infiltração e à perda de energia para a atmosfera; e o rochoso, relativamente seco e quente, devido à dificuldade de retençáo da água que, neste caso, facilmente infiltra e escoa e à perda de energia para a atmosfera.

Com base nestas considerações, pode-se dizer que as espécies bioindicadoras em análise permitem inferir ambientes do passado. $\mathrm{Na}$ área de estudo, revelou-se a existência de relictos de ambientes pretéritos. Estes se expressam no contexto das paisagens atuais através de uma morfologia e fisiologia que lhes permitem existir como testemunhos em áreas com microclima favorável. No dizer de Ab`Saber (2008), essas unidades de paisagens com presença de cactáceas correspondem ao que metaforicamente denominou de palimpsestos. (SILVA, 2009, p. 129).

Considera-se que esses estudos corroboram a hipótese inicial sobre a origem dos areais como naturais e, ao mesmo tempo, desconstroem conceitos de que essas áreas seriam espaços degradados. Considera-se ainda que, na origem, estes areais, enquanto naturais, não constituem áreas degradadas, o uso que é feito desses espaços no presente tende a degradá-los.

Enfim, para finalizar, indica-se uma última questão. 


\section{A MORFODINÂMICA DOS AREAIS E TRANSFIGURAÇÁO DA PAISAGEM LOCAL}

Para encaminhar esta questáo trazemos fotos mais atuais de areais e da regiáo de campos do RS. As Figuras 19 e 20 são registros do que Suertegaray (1987), ao finalizar o capítulo 3, interpretativo em sua tese, escreveu:

Assim, poderão esses areais não atingirem grandes dimensões, mas a mobilidade dos sedimentos por certo tenderá, de um lado, a assorear as várzeas e de outro, a transformar os atuais "campos de areia em campos de "pedra". O que do ponto de vista da apropriação pelo homem torna-se inviável e, quanto à trajetória da natureza promoverá toda uma transformação no balanço hídrico e morfogênico local. (SUERTEGARAY, 1987, p. 168).

Figura 19 - Área com substrato arenítico exposto, decorrente de processos erosivos, hídricos e eólicos, resultantes da dinâmica natural. Areal do Cerro do Chapéu/Figueira. Quaraí, 2017.

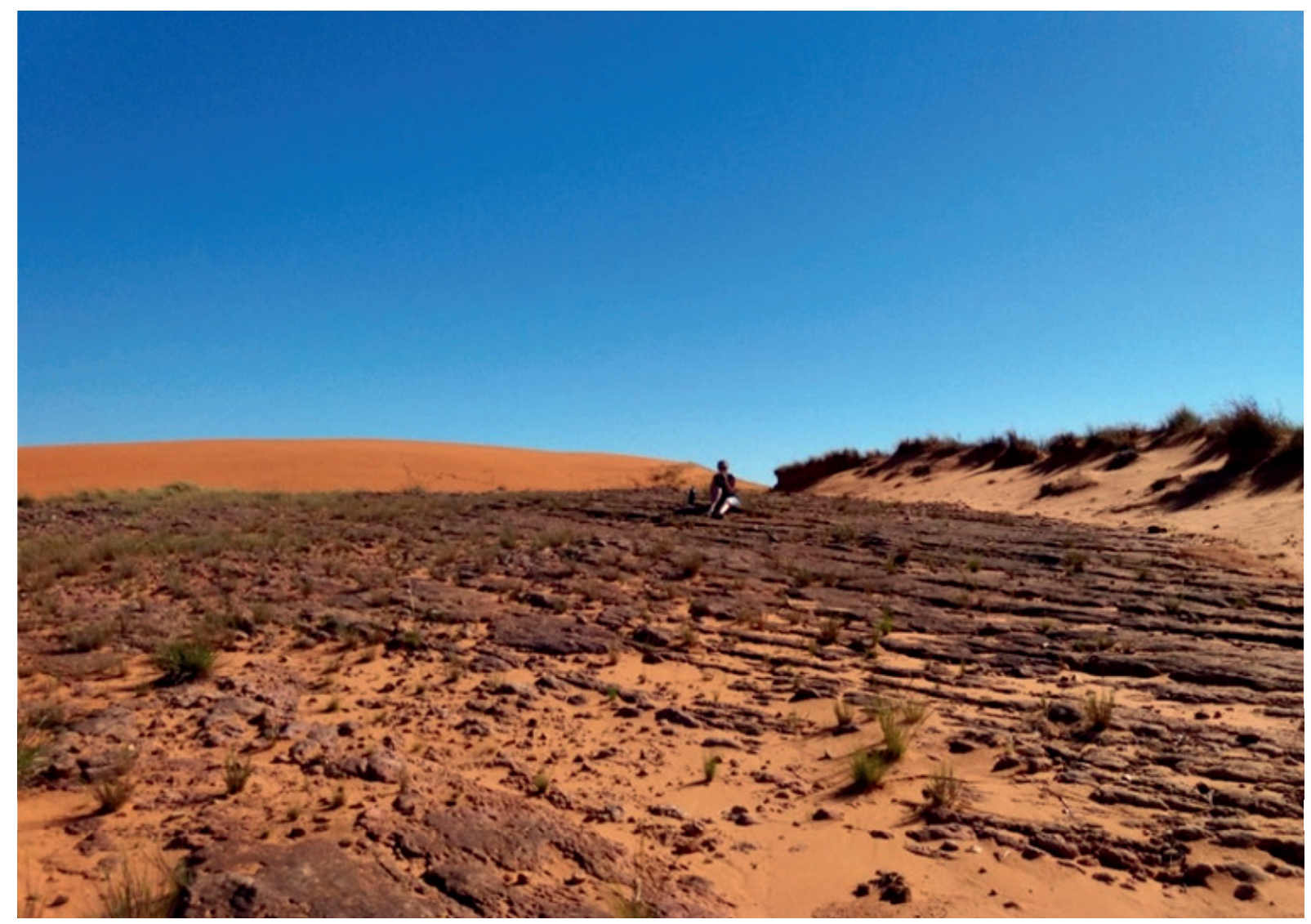

Fonte: foto de Dirce Suertegaray (2017) 
Figura 20 - Areal São João, decapamento do material arenoso constituinte do areal, devido à ação de processos hídricos. O barramento dos ventos pela cortina de eucalipto, com a finalidade de diminuir a expansão dos areais, reverteu o processo e acentuou a remoção da areia pelo escoamento superficial.

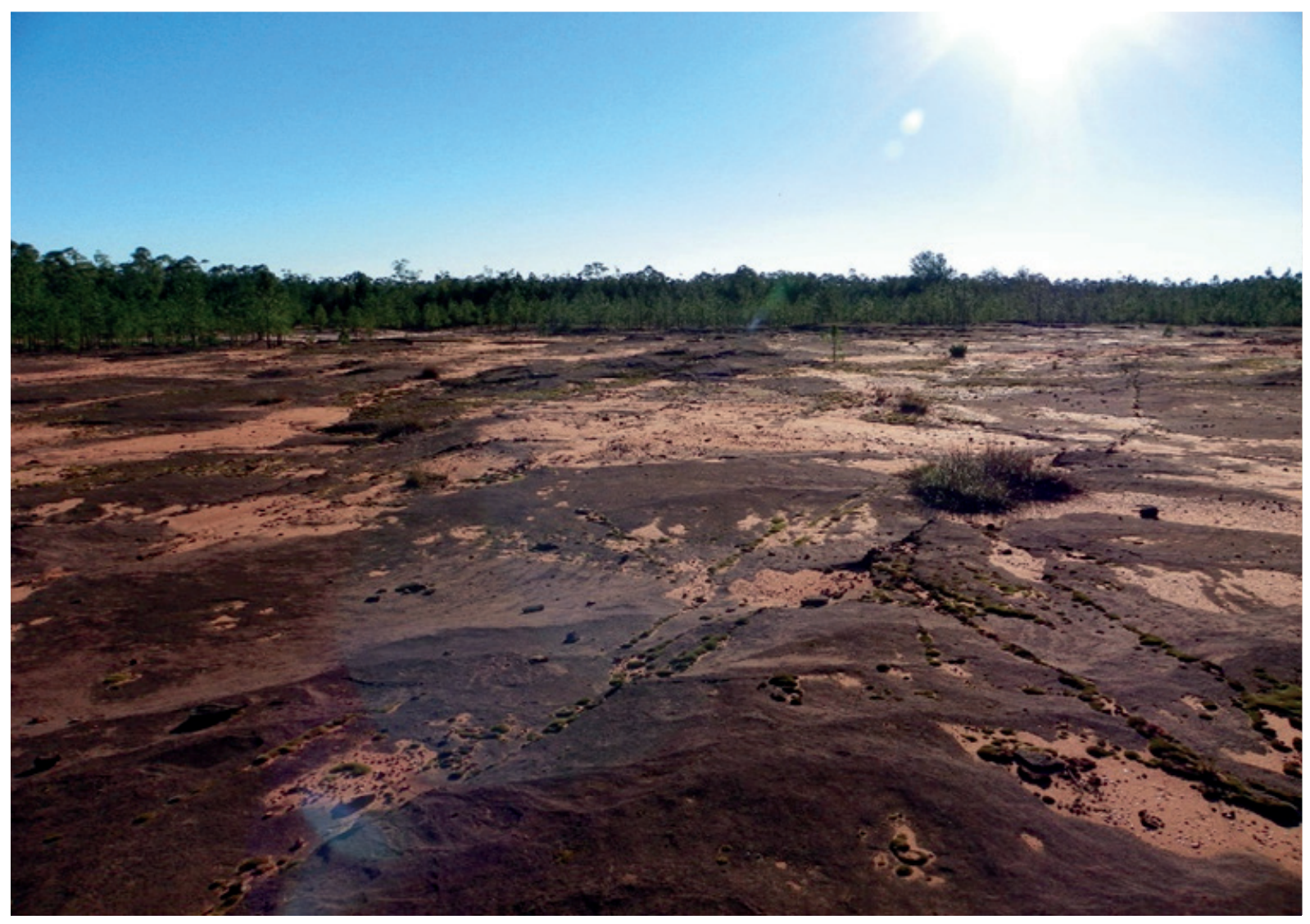

Fonte: Sidnei Luís Bohn Gass (2015)

A Figura 21 revela outro processo; neste caso, de intervenção antropogênica. Trata-se de remoção de areia para aproveitamento em obras de engenharia. A Figura 22 indica o resultado desse processo à jusante. Na medida em que o pacote superior, composto da unidade B (Unidade Areal), é removido, aflora a unidade A (Unidade Cati), com maiores teores de argila. Este pacote inferior, em períodos de chuvas, satura rapidamente e o escoamento superficial carreia sedimentos à jusante, deixando na superfície sinais desse escoamento na forma de sulcos.

A solução "técnica" encontrada para a contenção desse processo erosivo constitui-se na barreira de pneus. Esta, além de não resolver o problema, constitui uma intervenção em área degradada, pela atividade de extração de areia, num primeiro momento, associada à intensificação do escoamento superficial e às técnicas impróprias utilizadas. 
Figura 21 - Extração de areia para utilização em obras de engenharia. Areal do Cerro do Chapéu/Figueira, em Quaraí (2008).

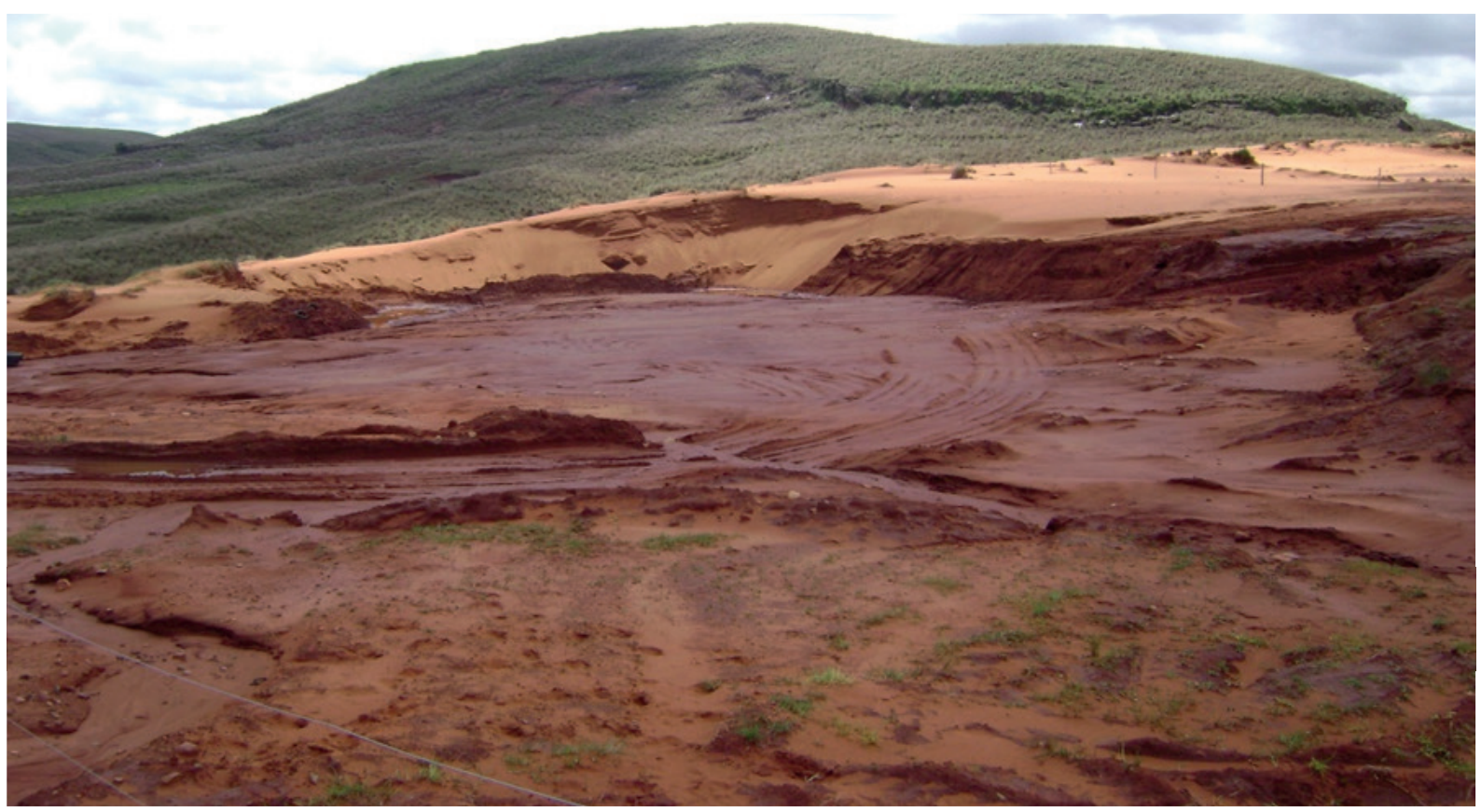

Fonte: foto de Dirce Suertegaray (2008)

Figura 22 - Barreira constituída de pneus, para conter o escoamento superficial, provocado pela retirada do sedimento arenoso sobreposto. Areal do Cerro da Panela/Figueira, em Quaraí.

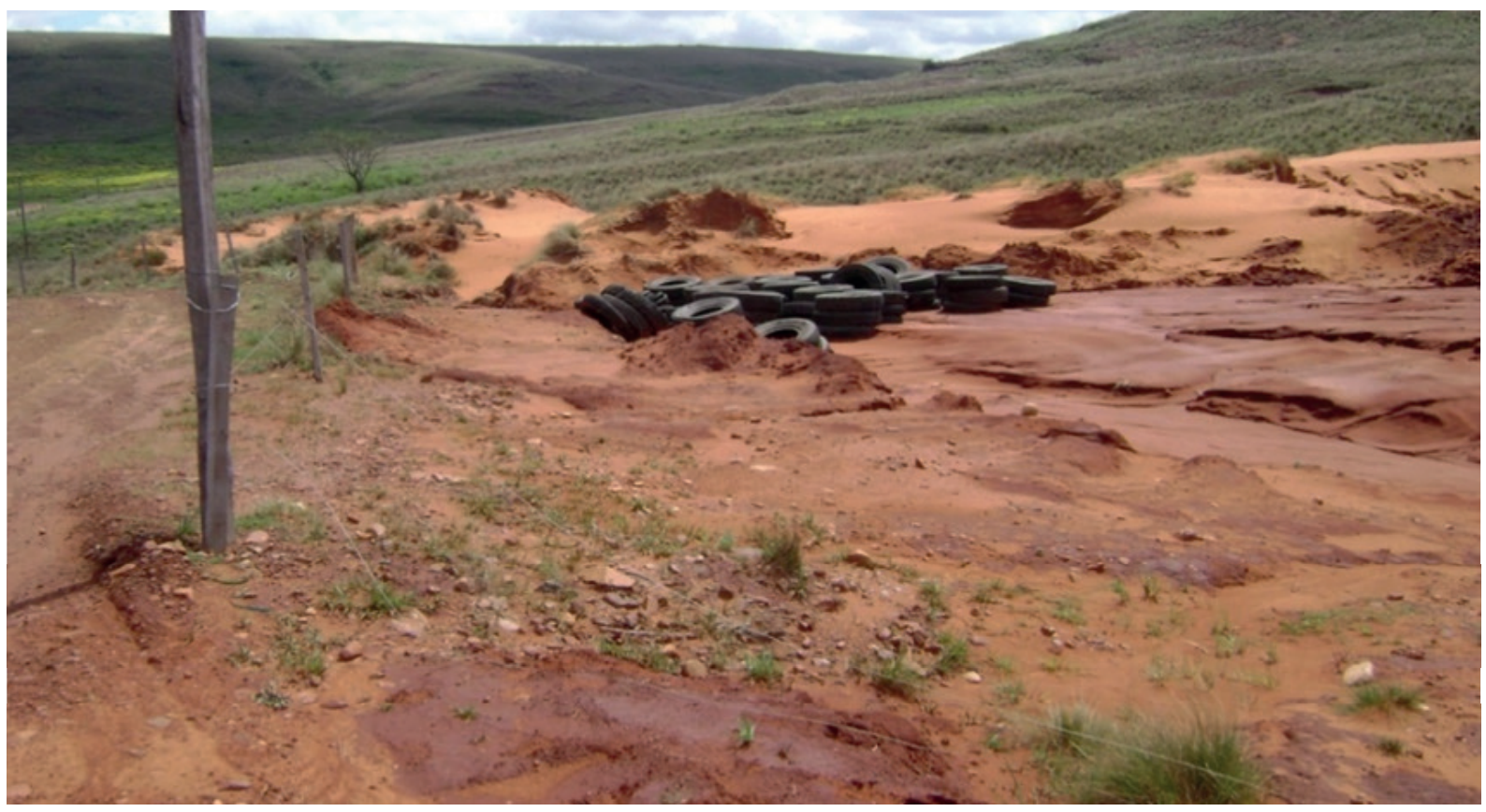

Fonte: foto de Dirce Suertegaray (2008) 
As imagens reproduzidas acima revelam dinâmicas atuais no interior dos areais. As Figuras 23A e 23B registram as transformaçóes da paisagem em áreas com ocorrência de areais. Esta transformação vem ocorrendo desde 2007, quando o governo do estado assume uma política de transformação da matriz econômica do pampa gaúcho, historicamente pastoril. Nesse sentido, foi estimulada a silvicultura, em particular, o plantio do eucalipto. Esta silvicultura se instalou na região dos campos gaúchos, através de compra de terras pela empresa sueco-finlandesa Stora Enso, que adquiriu terras em áreas de ocorrência de areais, facilitada pelo reduzido valor da terra, à época desvalorizada, por ser terra degradada.

A implantação desse projeto não ocorreu sem conflitos. Diferentes segmentos sociais se envolveram no debate: os Sem Terra (MST/Via Campesina), ambientalistas, acadêmicos, trabalhadores, políticos, empresários e órgãos ambientalistas do estado do RS. Não obstante, a silvicultura foi implantada, embora o corte não tenha se efetivado desde entáo (2008), o que já demandou questionamentos por parte dos grupos que deram apoio a essa iniciativa em particular, os políticos e prefeitos locais. A paisagem já se modificou. Hoje, os campos que caracterizaram essa parcela do território gaúcho deram lugar a uma paisagem de florestas homogêneas conforme pode ser observado abaixo: 
Figura 23A - Área de plantio do Eucalipto, no município de Manoel Viana. 2012. Figura 23B - Área de plantio de eucalipto, recobrindo campos e coxilhas (colinas), na Região da Campanha, RS. 2017.

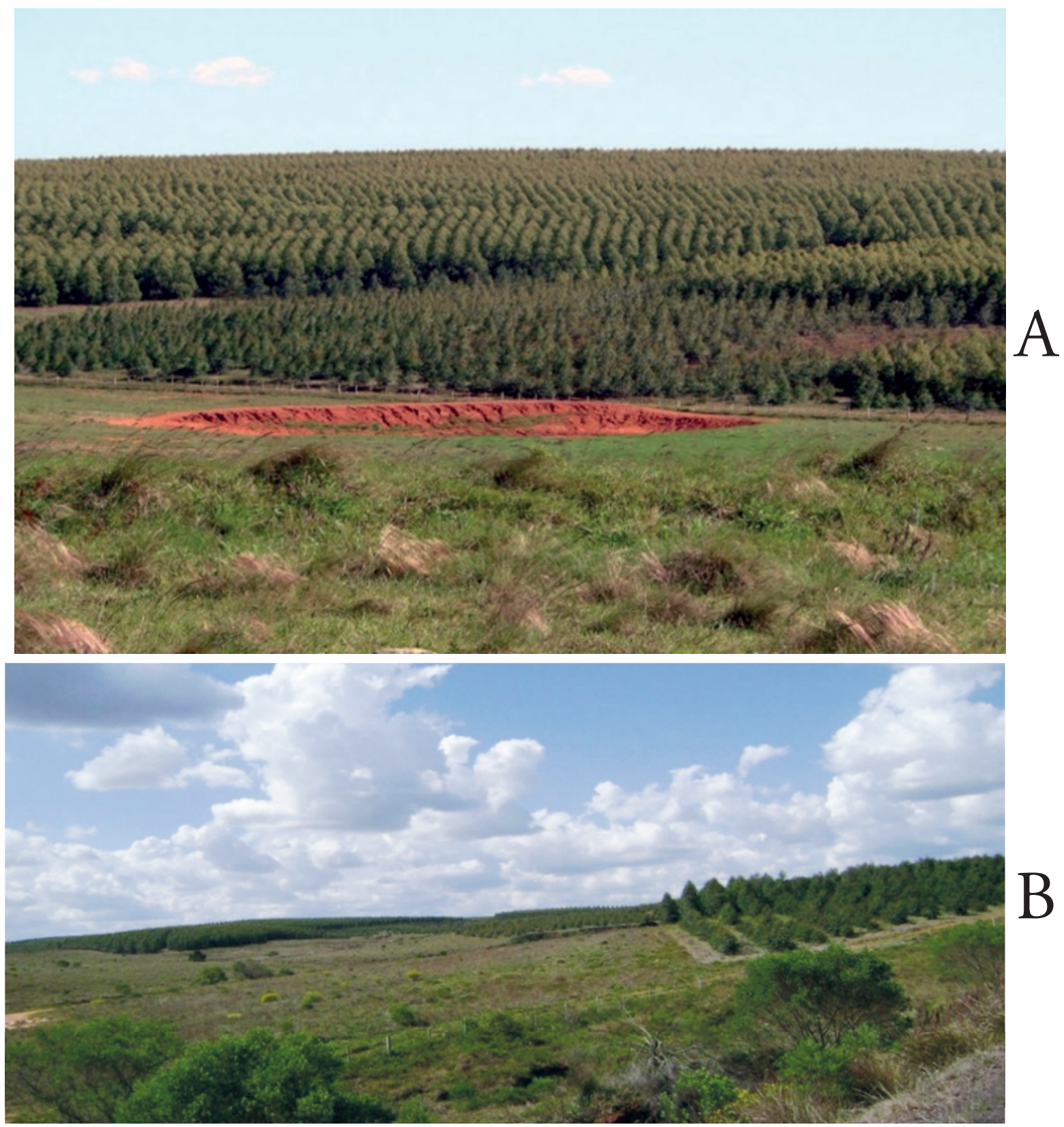

Fonte: a) foto de Dirce Suertegaray (2011/2017), b) foto de Dirce Suertegaray (2011/2017)

Para finalizar, tem-se duas imagens do Pampa, ou dos campos do Sul do Brasil (Figuras $24 \mathrm{~A}$ e 24B). Estes se constituem em áreas abertas, com domínio da vegetaçáo de campos e, como descrevia Ab Saber (1977), "de horizontes infindos". 
Figura 24A - Imagem dos campos de Quaraí, com presença de areais, ao fundo, à esquerda. Distrito do Areal. Figura 24B - Campos, mata-galeria e relevos residuais compõe com o horizonte longínquo a paisagem da região Sul do RS. BR-287, próximo ao Município de São Francisco de Assis.

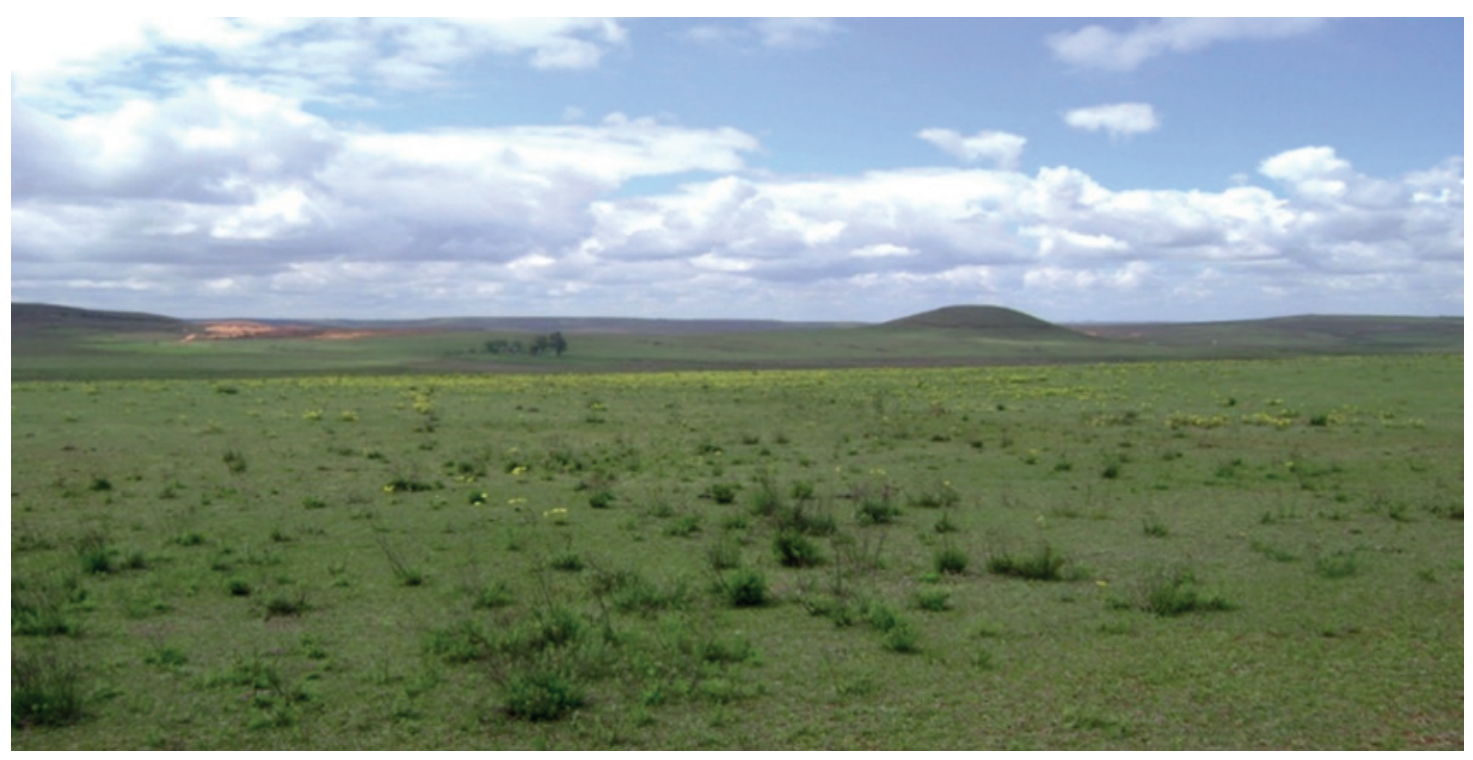

A

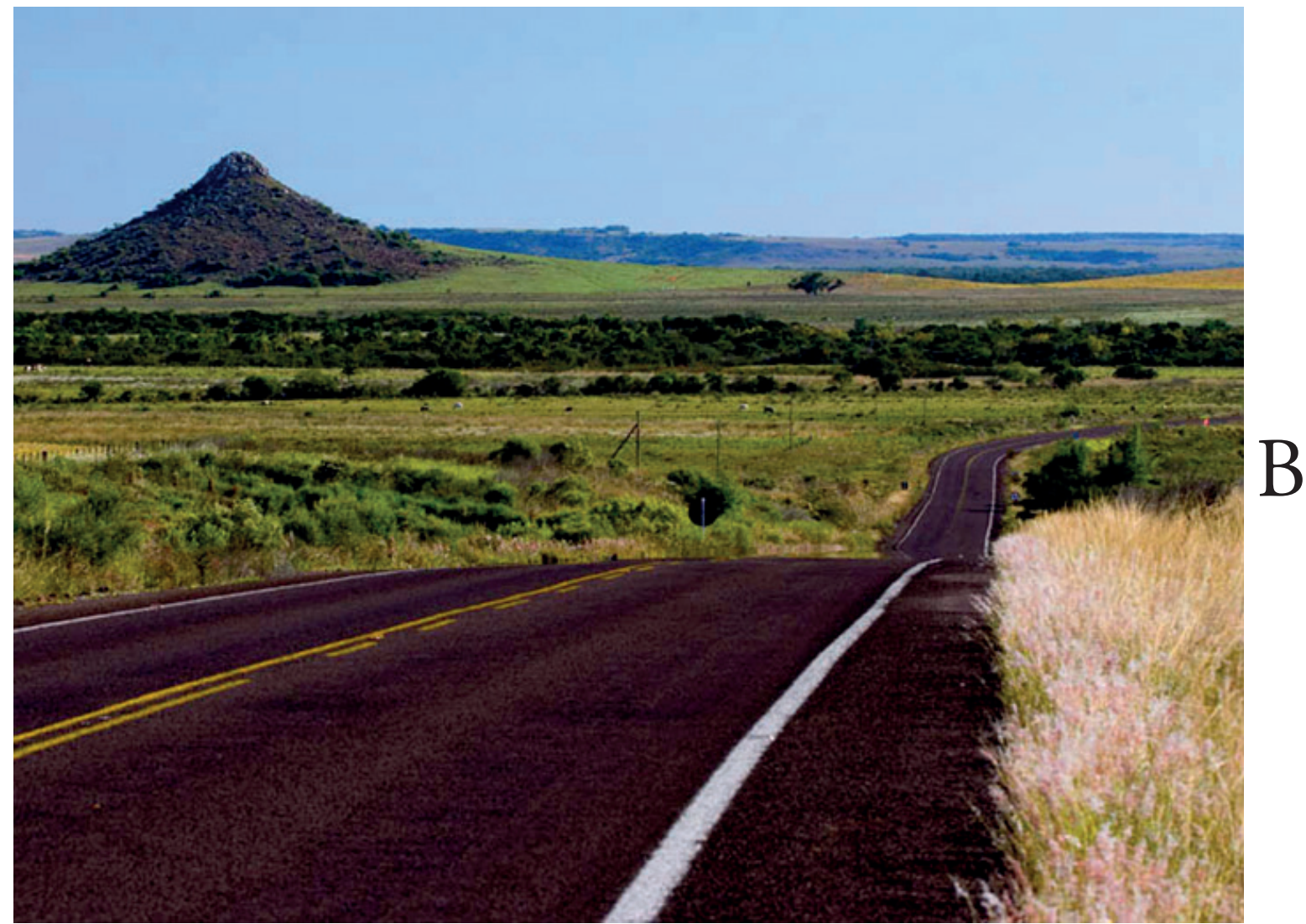

Fonte: a) foto de Dirce Suertegaray (2008), b) foto do grupo de pesquisas Arenização/Desertificação - questões ambientais, vinculado ao CNPq (2008) 
A última imagem, Figura 25, é reveladora do fechamento da paisagem, seja do ponto de vista visual, seja do ponto de vista da possibilidade de acesso a uma estância. Nestas, a rotina mudou: não se chega sem permissão; não se adentra como antes. As atuais empresas preservam o nome, ironicamente. Nesse exemplo, a Estância das Oliveiras é, hoje, "Estância dos Eucaliptos".

Figura 25 - Fazenda das Oliveiras: liberações e restrições. Município de Manoel Viana, RS

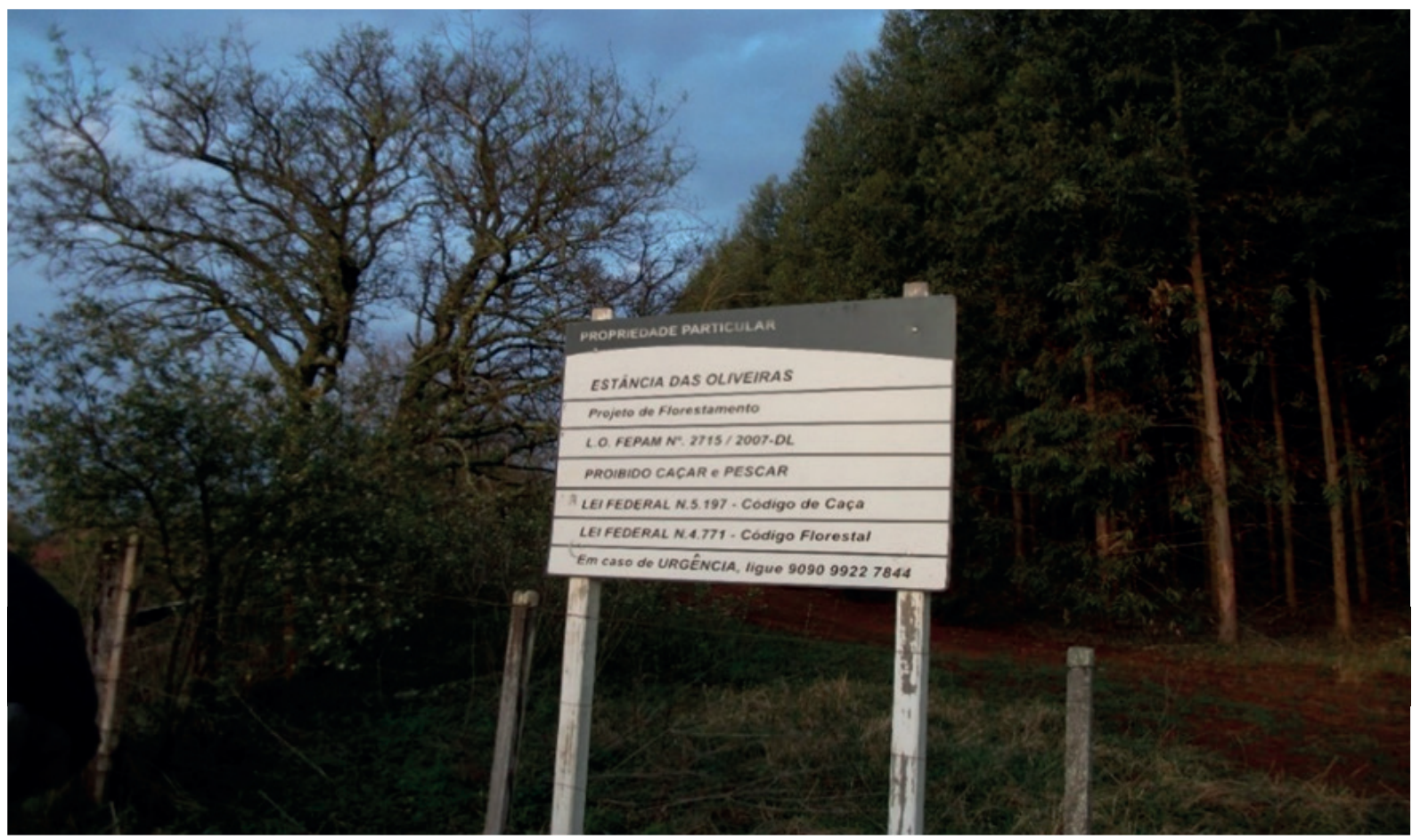

Fonte: foto de Dirce Suertegaray (2011)

\section{CONSIDERAÇÓES FINAIS}

Este texto resgata parte do conhecimento produzido sobre os processos de arenização. Seu conteúdo não é novo. As informaçóes aqui colocadas já são conhecidas dos pesquisadores da área. Esses conteúdos foram aqui expostos de forma didática, com o objetivo de apresentar um projeto de texto associado à imagem. Trata-se de um texto didático, com referências que podem auxiliar aos interessados em se aprofundar no tema. Em certa medida, com referências e indicaçóes bibliográficas, fica aqui uma proposição, quiçá aos professores que quiserem se iniciar no estudo do tema e, ao mesmo tempo, discutir com seus alunos sobre procedimentos de pesquisa, em um entendimento de pesquisa como perguntas a serem feitas e respondidas. 


\section{REFERÊNCIAS E INDICAÇÓES}

AB'SABER, A. Espaços Ocupados pela Expansão dos Climas Secos na América do Sul, por ocasiáo dos Períodos Glaciais Quaternários. Paleoclimas. No. 3, São Paulo: Instituto de Geografia, Universidade de São Paulo (USP), 1977a. 19p.

Os domínios Morfoclimáticos na América do Sul: primeira aproximação. Geomorfologia, no 52. Sáo Paulo: Instituto de Geografia, Universidade de São Paulo (USP), 1977b. 23p.

. Palimpsestos Ecológicos. Scientific American Brasil. São Paulo, ano 6, n. 68, p. 98, jan./2008.

AVÉ-LALLEMANT, R. Viagem pela Província do Rio Grande do Sul (1858). São Paulo: Editora Itatiaia e EDUSP, 1980.

BELLANCA, E. Uma contribuiçáo para a explicaçáo da gênese dos areais do Sudoeste do Rio Grande do Sul. 2002. 88 f. Dissertação (Mestrado em Geografia) - Programa de Pós-Graduaçáo em Geografia, Universidade Federal do Rio Grande do Sul (UFRGS), Porto Alegre, 2002.

MARESCA, S. O silencio das imagens. In: SAMAIN, Etienne (Org.). Como pensam as imagens. Campinas: Editora UNICAMP, 2012. p. 37-40.

MILDER, S. E.S. Arqueologia do Sudoeste do Rio Grande do Sul: uma perspectiva geoarqueológica. 2000. 174 f. Tese (Doutorado em Arqueologia) - Faculdade de Filosofia, Letras e Ciências Humanas, Universidade de São Paulo (USP), São Paulo, 2000.

SCOPEL, I. et al. Neossolos Quartzarênicos Órticos das áreas de areais do sudoeste do Rio Grande do Sul: características físicas e morfológicas. In: SUERTEGARAY, Dirce M.A.; SILVA, Luis A.P.; GUASSELLI, Laurindo A. (orgs.). Arenizaçáo: natureza socializada. Porto Alegre: Editora ComPasso lugar-cultura e Imprensa Livre, 2012. p. 503-542.

SILVA, Dakir L. M. Microclima e bioindicadores paleoclimáticos em paisagens com ocorrência de areais em Sáo Francisco de Assis, RS, Brasil. 2009. 152 f. Tese (Doutorado em Geografia) - Programa de Pós-Graduação em Geografia, Universidade Federal do Rio Grande do Sul (UFRGS), 2009.

SILVA, L.A.P. Narrativas das percepçóes e conectividades de caminhantes nas paisagens dos areais pampeanos: perspectivas ambientais para geração de ambiências. 2008. 155 f. Dissertação (Mestrado em Geografia) - Programa de Pós-Graduação em Geografia, Universidade Federal do Rio Grande do Sul (UFRGS), Porto Alegre, 2008.

SUERTEGARAY, D.M.A. A Trajetória da Natureza: um estudo geomorfológico sobre os areais de Quarai-RS. 1988. 243 f. Tese (Doutorado em Geografia) - Faculdade de Filosofia, Letras e Ciências Humanas, Universidade de São Paulo (USP), São Paulo, 1988.

Deserto Grande do Sul: controvérsia. Porto Alegre: Editora da Universidade/ UFRGS, 1992. p. 71. 
Deserto Grande do Sul: controvérsia. $2^{\mathrm{a}}$ ed. Porto Alegre: Editora da Universidade/UFRGS, 1998. p. 74.

Geografia e Imagem: atividade de campo, paisagem e patrimônio natural. In: JACINTO. R. (Coord.). Transversalidades - Fotografia sem Fronteiras. $1^{\text {a }}$ ed., vol. 1 Guarda: Centro de Estudos Ibéricos, 2017. p. 26-29.

SUERTEGARAY, D.M.A.; GUASSELLI, L.A.; VERDUM, R. Atlas da Arenização Sudoeste do Rio Grande do Sul. Porto Alegre: Secretaria da Coordenação e Planejamento do Estado do Rio Grande do Sul e Secretaria da Ciência e Tecnologia Governo do Estado do RS, 2001,1 ${ }^{\mathrm{a}}$ ed, 2001. p. 84.

SUERTEGARAY, D.M.A.; SILVA, Luis A. P.; GUASSELLI, L.A. (Orgs.). Arenização: natureza socializada. Porto Alegre: Editora ComPasso lugar-cultura e Imprensa Livre, 2012. p. 597.

Recebido para publicação em abril de 2018

Aceito para publicação em maio de 2018 